
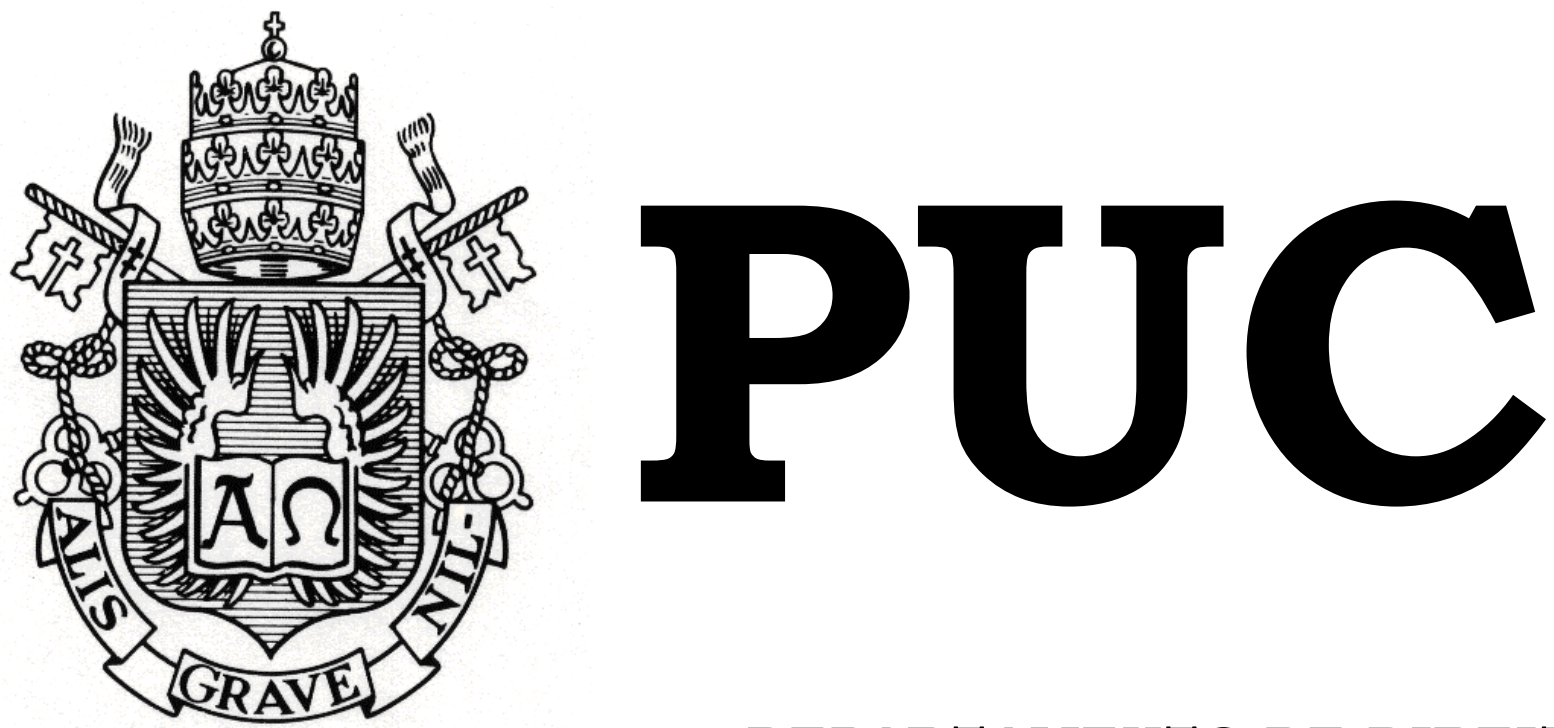

DEPARTAMENTO DE DIREITO

\title{
A TRAJETÓRIA DO ABANDONO AFETIVO SOB A ÓTICA JURISPRUDENCIAL, DOUTRINÁRIA E LEGISLATIVA
}

por

Bruno Lima Soares Pestana

ORIENTADORA: Profa. Inês Alegria Rocumback

\section{1}

PONTIFÍCIA UNIVERSIDADE CATÓLICA DO RIO DE JANEIRO

RUA MARQUÊS DE SÃO VICENTE, 225 - CEP 22453-900

RIO DE JANEIRO - BRASIL 


\section{A TRAJETÓRIA DO ABANDONO AFETIVO SOB A ÓTICA JURISPRUDENCIAL, DOUTRINÁRIA E LEGISLATIVA}

Por

BRUNO LIMA SOARES PESTANA

Monografia

apresentada

ao

Departamento de Direito da Pontifícia Universidade Católica do Rio de Janeiro (PUC-Rio) para a obtenção do Título de Bacharel em Direito.

Orientadora: Profa. Inês Alegria Rocumback 


\section{Agradecimentos}

Deixou aqui o meu sincero agradecimento a todos aqueles que foram essenciais para eu pudesse chegar até esse momento e prioritariamente:

Aos meus pais, responsáveis por tudo de bom que tive a oportunidade de construir em minha vida;

A minha irmã, por todo o carinho e preocupação em todos os momentos;

Aos amigos, em geral, feitos ao longo da vida e os conquistados nesses 5 (cinco) anos de faculdade, que fizeram essa trajetória ser mais prazerosa e, em especial ao Bruno Pittella, Bruna Hauser, Filipi Azambuja, Maria Fernanda Marques e Pedro Henrique Cordeiro, por toda ajuda nos bons e maus momentos;

Aos professores Bruno Vaz e Inês Alegria que fizeram despertar meu interesse pelo Direito de Família, sendo esta última também uma orientadora extremamente acessível, atenciosa e paciente;

E, fundamentalmente, a minha namorada, Estela Tatsch, por ser minha amiga, companheira e parceira de sonhos, que foi ouvinte, leitora e crítica durante toda a elaboração desse trabalho e é responsável pelos meus maiores momentos de alegria todos os dias. 


\section{Resumo}

O presente trabalho pretende, essencialmente, demonstrar quais são os posicionamentos da jurisprudência, da doutrina e do Poder Legislativo federal a respeito da possibilidade de indenização por danos morais decorrentes de abandono afetivo.

Para tanto, explana-se quais são os deveres paternos e os direitos dos filhos estipulados pelo ordenamento jurídico brasileiro e de que maneira isso refletiu na forma como os Tribunais passaram a julgar os atos abandônicos dos genitores e os pedidos de indenização realizados pelos filhos.

Visando esse fim, nos valemos das duas decisões do Superior Tribunal de Justiça como marcos temporais, de modo que sejam destacados os mais relevantes julgados dos Tribunais de Justiça que as antecedem, sem jamais esquecer, dos pareceres doutrinários sobre os aspectos principais desse debate.

E por fim, apontamos quais os projetos em tramitação no Congresso Nacional que visam acabar com a controvérsia a respeito dessa temática e regular, de uma vez por todas, a matéria em questão.

\section{Palavras-Chave}

Abandono afetivo- danos morais- indenização- julgados- ato ilícitocuidado- afeto- paternidade responsável- dignidade da pessoa humanamelhor interesse da criança- convivência familiar- projetos de lei 


\section{Sumário}

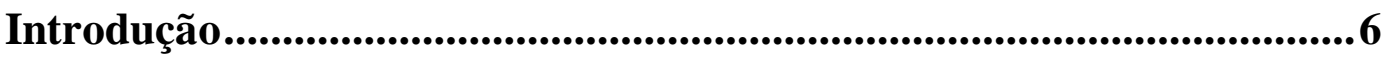

Capítulo 1- A Importância da Criança no Seio Familiar e os Valores que Fundamentam o Pleito Indenizatório ............................................9

1.1- A Nova Imagem da Criança na Sociedade Brasileira e as Mudanças nos Deveres dos Genitores

1.2- O Afeto e o Cuidado em Foco: O Surgimento de Dois Novos Protagonistas e as Consequências de suas Ausências 12

Capítulo 2- O Início das Manifestações Jurisprudenciais e a Primeira Decisão do Superior Tribunal de Justiça..............................................17

2.1- O Despertar Jurisprudencial ............................................... 17

2.2- O Primeiro Grande Julgado ....................................................25

Capítulo 3- O Reflexo da Posição do STJ Sobre os Tribunais de Justiça: A Sombra de uma Decisão...............................................31

Capítulo 4- A Nova Postura do Tribunal Superior: uma Mudança Paradigmática ........................................................................60

Capítulo 5- A Questão em Debate no Congresso Nacional ....................70

5.1- As Proposições do Projeto de Lei n 700 de 2007 e sua Tramitação no Senado Federal ............................................................. 70

5.2- O Projeto de Lei no 4.294 de 2008 da Câmara dos Deputados......... 80

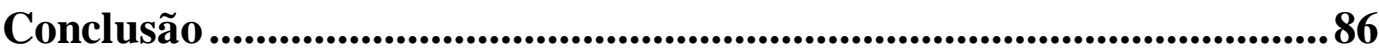

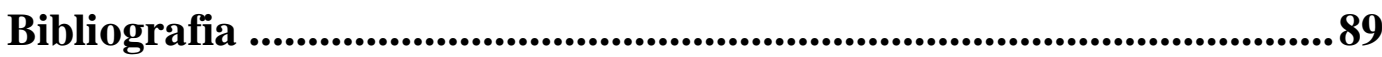




\section{Abreviações}

Art - Artigo

CC- Código Civil

CCJ- Comissão de Constituição e Justiça

CRFB- Constituição da Republica Federativa do Brasil

Des- Desembargador

Dr- Doutor

ECA- Estatuto da Criança e do Adolescente

MG- Minas Gerais

Min- Ministro

PL- Projeto de Lei

PLS- Projeto de Lei do Senado Federal

Rel- Relator

REsp- Recurso Especial

RJ- Rio de Janeiro

RS- Rio Grande do Sul

SC- Santa Catarina

SP- São Paulo

STJ- Superior Tribunal de Justiça

TJ- Tribunal de Justiça 


\section{Introdução}

Vivemos em uma sociedade na qual cada vez mais o tempo deixa de ser um aliado e passa a ser um inimigo. Se antes o tempo era visto como um remédio para curar as mais profundas dores, hoje, ele é um vilão que impede concretizações. Vinte e quatro horas não são mais suficientes para que se realizem todas as tarefas de um dia.

A troca de informações é tão veloz e intensa, que muito é lido, mas muito pouco é absorvido ou aproveitado. A indústria fomenta um consumismo cada vez mais desenfreado, em que tudo deve ter um curto prazo de validade e ser rapidamente trocado. Tudo é descartável, nada é durável.

A sociedade cada vez mais se mostra composta por indivíduos com olhos voltados apenas para sua própria vida, que se preocupam, demasiadamente, com a vida do próximo, mas não com o próximo propriamente dito.

Muito se cultua o corpo, se julgam as aparências e nada sobra de preocupação com o interior. Vive-se em ciclo esquizofrênico em que cada um só "olha para o próprio umbigo", mas que o ideal que se busca é ser a "imagem e semelhança" de um outro indivíduo posto como referência.

Tudo e todos estão conectados o tempo todo. As relações interpessoais vêm sendo substituídas, insistentemente, por relações distantes e impessoais. Não mais se dialoga, se trocam mensagens. Até a boa e velha conversa de bar, vem sendo substituída por pessoas ao redor de uma mesa, sem mal se falarem, cada um no seu "smartphone" de última geração.

Nesse contexto em que todo mundo tem pressa, os mais frágeis são as maiores vítimas. Se não existe tempo que possa ser perdido, também não existe tempo para o cuidado. Cuidar exige tempo, dedicação e atenção. 
Mas se existe uma cultura de massa sendo imposta pelo poder econômico, também existem aqueles que se preocupam com a construção de uma sociedade justa e solidária. E não existe justiça social sem a proteção de valores que priorizem o bem-querer dos mais desamparados. Por isso, é importante que exista um contrapeso impulsionado pelos instrumentos e aparatos legais, que freie esse impulso selvagem e individualista, imposto por aqueles que detêm os fatores dominantes de poder. Do contrário, apenas os mais fortes e mais bem preparados são capazes de gozar de uma vida digna.

Diante desse quadro, é fundamental que se ponha em prática todos os valores previstos em uma Constituição Federal que fora criada a partir dos anseios de uma sociedade vitimada por anos de uma ditadura.

Logo, não há espaço para que se permita o crescimento de uma cultura de pais que não tem tempo ou interesse por seus filhos e preferem relegá-los a segundo plano, quando a Carta Magna do país enaltece valores com a solidariedade, a dignidade da pessoa humana e cidadania.

Quando a Lei suprema do nosso ordenamento jurídico estabelece como deveres paternos a convivência familiar, a educação, a criação e todas as demais derivações do ato de cuidar, não existem desculpas legais e não apenas éticas e morais, que autorizem a impunidade de atos abandônicos.

E se mesmo com essas imposições evidentes e com a demonstração, por parte da psicologia e da psicanálise, da potencialidade de danos do desamparo afetivo, alguns pais decidirem por abandonarem seus filhos, não há como se negar o direito à reparação para as vítimas desse ato.

Por isso, com o presente trabalho, visamos demonstrar os princípios, valores e deveres, trazidos pela Constituição Federal de 1988, que fundamentam a possibilidade de indenização por danos morais para os filhos que sejam vítimas de abandono afetivo. 
Ademais, pretendemos fazer uma análise e compilação das principais decisões judiciais acerca do tema em questão, com maior destaque para as duas decisões do Superior Tribunal de Justiça, intercalando com os mais diversos entendimentos doutrinários tanto a respeito dessas decisões, quanto ao assunto em si.

E por fim, buscamos demonstrar quais são os Projetos de Lei que existem no Congresso Nacional que tratam sobre a matéria, e qual o seu conteúdo e tramitação.

Entendemos ser esse um problema bastante grave e que necessita de um maior destaque. Afinal de contas, abandonar afetivamente as nossas crianças, significa criar uma sociedade doente e abandonada a sua própria sorte. 


\section{Capítulo 1- A Importância da Criança no Seio Familiar e os Valores que Fundamentam o Pleito Indenizatório}

O presente capítulo tem por intuito fazer uma explanação em linhas gerais da grande responsabilidade que foi atribuída aos pais pelo ordenamento jurídico brasileiro e de que maneira isso acarretou na elevação do afeto a aspecto essencial na criação das crianças e adolescentes nos dias de hoje.

\section{1- A Nova Imagem da Criança na Sociedade Brasileira e as Mudanças nos Deveres dos Genitores}

No transcorrer da história da humanidade, o olhar sob a figura da criança foi sofrendo mudanças gradativas e, sempre que isso ocorria também se alterava a função e a imagem da mesma perante a sociedade e, consequentemente, o seu lugar na família.

Tal panorama é fruto do fato de que o conceito do que é ser criança é uma construção social em progressiva e eterna evolução, até porque, se tomarmos por base o lapso temporal que transcorreu do momento em que o mesmo passou a ter destaque até os dias de hoje, podemos afirmar que se trata, em termos de história, de um conceito um tanto quanto recente. ${ }^{1}$

Assim, no entendimento de Rosa Martins, podemos dizer que:

"A consciência de que a criança é um ser com características e especificidades próprias teve consequências importantes no que diz respeito ao papel da criança dentro da família, em particular na relação com os pais, e fora dela". ${ }^{2}$

Na sociedade brasileira contemporânea, ao contrário do que ocorria em outros tempos, a criança tem cada vez mais respeitado o seu devido

\footnotetext{
${ }^{1}$ MARTINS, Rosa. "Responsabilidades Parentais no século XXI: a tensão entre o direito de participação da criança e a função educativa dos pais" IN PEREIRA, Tânia da Silva. OLIVEIRA, Guilherme de. "Cuidado \& Vulnerabilidade. Editora Atlas S.A. São Paulo. 2009.

${ }^{2}$ Ibdi.
} 
lugar social, the sendo atribuídas pelo ordenamento jurídico as garantias e proteções que são inerentes a sua condição de sujeito especial de direitos.

Com o advento da Constituição Federal de 1988 e o valoroso suporte das leis $8.069 / 90$ e 10.406/2002, mais conhecidas, respectivamente, como Estatuto da Criança e do Adolescente e Novo Código Civil, passa a vigorar uma lógica que institui uma nova gama de direitos, que buscam garantir que a infância seja gozada em sua plenitude, e deveres, que devem ser observados pelos pais para que se concretize um desenvolvimento saudável e efetivo da sua prole.

Sob o manto da Carta Magna, o princípio da dignidade da pessoa humana, elencado em seu artigo $1^{\circ}$, inciso III, passou a ser uma das bases do Estado do Democrático de Direito e, isso, consequentemente, também foi transportado para o Direito de Família. Também dentro do seio familiar, passou-se a buscar a concretização dessa dignidade, principalmente, com relação ao desenvolvimento da criança e do adolescente.

Nas palavras de Ana Carolina Brochado Teixeira:

"O Direito de Família, por seu turno, viu-se compelido a acompanhar essa evolução, sob pena de descumprir sua função primordial, que é reger fatos sociais. Mas isso apenas se realizou em virtude da virada hermenêutica que perpassou todo o Direito Civil, por nós conhecida como fenômeno da constitucionalização ou personalização do Direito Civil, através do qual a pessoa humana assumiu o centro da ordem jurídica". ${ }^{3}$

Diante deste novo parâmetro, o princípio do Melhor Interesse da Criança e do Adolescente passou a ser o principal guia para se garantir a efetiva realização da dignidade humana desses indivíduos e o mais relevante aspecto a ser analisado no deslinde de questões que os envolva.

Contudo, para que os novos valores e princípios constitucionais tivessem eficácia e as normas do Estatuto da Criança e do Adolescente e do Código Civil de 2002, referentes ao Direito de Família, não fossem apenas

\footnotetext{
${ }^{3}$ TEIXEIRA, Ana Carolina Brochado. "Responsabilidade Civil e Ofensa à Dignidade Humana". IN Revista Brasileira de Direito de Família. Ano VII. Nº32. Out-Nov 2005, p.139.
} 
"letra morta", era necessário que fossem estabelecidos, aos pais e a sociedade, novos deveres que garantissem que estes respeitariam e zelariam pela nova condição do menor dentro da sociedade.

Para tanto, a Constituição da República Federativa do Brasil, trouxe em seu artigo 227, caput, a seguinte previsão:

"É dever da família, da sociedade e do Estado assegurar à criança, ao adolescente e ao jovem, com absoluta prioridade, o direito à vida, à saúde, à alimentação, à educação, ao lazer, à profissionalização, à cultura, à dignidade, ao respeito, à liberdade e à convivência familiar e comunitária, além de colocá-lo a salvo de toda forma de negligência, discriminação, exploração, violência, crueldade e opressão". (grifo nosso). ${ }^{4}$

Nesse sentido, Rodrigo da Cunha Pereira sustenta que:

"A paternidade/maternidade deixou de ser apenas um conjunto de competências atribuídas aos pais, convertendo-se em um conjunto de deveres para atender ao melhor interesse do filho, principalmente, no que tange à convivência familiar, que deve ser vista de forma independente da existência, ou não, do tipo de relacionamento entre os pais". 5

Resta evidente, portanto, que o princípio do Melhor Interesse da Criança e do Adolescente precisa, necessariamente, andar lado a lado com outro princípio fundamental dentro do núcleo familiar, a saber: o princípio da paternidade responsável.

Ser pai ou mãe nos dias de hoje, não é apenas pôr mais uma vida no mundo, mas sim, cuidar, educar, ser presente e participativo e auxiliar no completo desenvolvimento desse novo indivíduo, o que veremos de forma mais detida no momento oportuno.

Cabe salientar ainda, que a referida conduta zelosa dos pais para com os filhos, não é uma escolha daqueles que buscam ser os melhores genitores possíveis para os seus rebentos, mas sim uma obrigação imposta pela Lei

\footnotetext{
${ }^{4}$ BRASIL, Constituição (1998). Constituição da República Federativa do Brasil. Distrito Federal: Senado, 1988.

${ }^{5}$ PEREIRA, Rodrigo da Cunha. "Responsabilidade Civil por Abandono Afetivo". IN Revista Brasileira de Direito das Famílias e Sucessões. No 29. Ago-Set 2012. Disponível em: http://www.magisteronline.com.br.
} 
Maior do ordenamento pátrio, conforme se verifica nos artigos $226, \S 7^{\circ} \mathrm{e}$ $229:^{6}$

“Art. 226, §7: Fundado nos princípios da dignidade da pessoa humana e da paternidade responsável, o planejamento familiar é de livre decisão do casal, competindo ao Estado propiciar recursos educacionais e científicos para o exercício desse direito, vedada qualquer forma coercitiva por parte das instituições oficiais ou privadas." (grifo nosso).

"Art. 229: Os pais têm o dever de assistir, criar e educar os filhos menores, e os filhos maiores têm o dever de ajudar e amparar os pais na velhice, carência ou enfermidade." (grifo nosso)

Portanto, somente com a junção prática dos princípios do Melhor Interesse da Criança e do Adolescente e da paternidade responsável é que se começa a devida pavimentação de um caminho que conduzirá rumo à efetivação da dignidade humana daqueles que ainda se encontram em formação.

\section{2- O Afeto e o Cuidado em Foco: O Surgimento de Dois Novos Protagonistas e as Consequências de suas Ausências}

Em face de todas as mudanças já relatadas nos parágrafos anteriores, houve uma profunda alteração na estrutura familiar e na forma da sociedade enxergar essa entidade.

Foi colocada uma "pá de cal” em cima da figura da família hierarquizada e patriarcal, na qual o pai era o provedor e senhor supremo do lar, que tinha seu respaldo no Código Civil de 1916.

Hoje, não só inexiste espaço para esse tipo de pirâmide familiar, como também se exige que os pais, e isso inclui tanto a figura materna quanto a paterna, cumpram todos os deveres que a lei lhe impõe e isso vai muito além do simples sustento material.

\footnotetext{
${ }^{6}$ BRASIL, Constituição (1998). Constituição da República Federativa do Brasil. Distrito Federal: Senado, 1988
} 
Conforme já avençado anteriormente, a Constituição impõe aos pais o dever de educar, criar, apoiar, dar todo o suporte necessário para o saudável desenvolvimento da criança e do adolescente, enfim, cumprir todas as responsabilidades que são inerentes à sua posição. Afinal de contas, em um mundo globalizado como o atual, que se renova na agilidade de um "clique" e que gira na velocidade com que se consomem informações via internet, o mínimo que se espera é que os pais estejam cientes das obrigações que assumem ao decidir por ter um filho.

Isto posto, mostra-se ultrapassado o simplório argumento usado por muitos genitores de que "eu compro tudo para essa criança, não the falta nada". O que muitos não entendem, mas que desde 1988 já é um dever constitucional, é que necessário se fazer pai/mãe em todos os aspectos. O sustento material não basta mais por si só para abarcar as obrigações para com os filhos.

Nesse sentido, leciona Rolf Madaleno:

"Foi-se o tempo dos equívocos das relações familiares gravitarem exclusivamente na autoridade do pai, como se ele estivesse acima do bem e do mal apenas por sua antiga função provedora, sem perceber que deve prover seus filhos muito mais de carinho do que de dinheiro, ou vantagens patrimoniais." 7

O Estado Democrático de Direito se pauta no princípio da dignidade da pessoa humana e o Direito de Família, por sua vez, deve buscar concretizar a dignidade da criança e do adolescente dentro da família. E isso, passa pela necessidade de se garantir um desenvolvimento pleno e saudável dos mesmos.

Contudo, tal desenvolvimento só é possível em uma família que ofereça todo o suporte que uma criança ou um jovem necessitam, ou seja, em um lar que the seja oferecido carinho, cuidado e afeto.

\footnotetext{
7 MADALENO, Rolf. "O custo do abandono afetivo". Disponível em: http://www.rolfmadaleno.com.br/rs/index.php?option=com_content\&task=view\&id=943\&Itemid= 39. Acessado em 15/11/2012.
} 
Tal lógica também é exaltada por Ana Carolina Brochado Teixeira que dispõe da seguinte forma:

"Para que isso aconteça, faz-se necessário presença, afeto, limite, segurança,
proteção, exemplo, enfim, atributos que não se esgotam no dever de sustento e no
pagamento de alimentos. É preciso muito mais do que isso... É necessário
exercício de paternidade e maternidade em plenitude, com tempo, dedicação,
disponibilidade, trabalho... É necessário preencher uma demanda de amor e afeto
que é inerente ao ser humano, principalmente daquele que está em fase de
crescimento, de firmar seus valores, de desenvolvimento da personalidade." Nessa mesma linha de raciocínio, se destaca também a posição de Maria Isabel Pereira da Costa nos seguintes termos:

"Crescer em família é um direito da criança, que tem o direito de receber afeto e os devidos cuidados para poder se desenvolver plenamente. A doutrina da Proteção Integral é baseada nas necessidades próprias e peculiares das crianças e adolescentes que, pela sua condição peculiar de pessoas em desenvolvimento, necessitam de proteção integral, diferenciada e especializada". ${ }^{9}$

Desse modo, fica nítida a importância que o afeto e o cuidado assumiram dentro do contexto familiar, sendo bastante grifada pela doutrina a presença do direito do filho de receber essa proteção especial, já que os mesmos são primordiais para o seu desenvolvimento, que é objetivado pela lei, e do dever dos pais de fornecê-los àqueles a quem colocaram no mundo.

É nesse cenário, que surge a discussão quanto à possibilidade ou não de se buscar judicialmente uma reparação por conta da negação a esse acompanhamento diferenciado que deveria ser conferido ao filho, em decorrência de um dever de cuidado que é obrigação de todo pai e mãe.

E essa discussão, tem se tornado uma das questões mais controvertidas dentro deste ramo do direito, tendo ganhado cada vez mais destaque nos últimos anos e acarretado as mais diversas posições não só na doutrina, mas também na jurisprudência.

\footnotetext{
${ }^{8}$ TEIXEIRA, Ana Carolina Brochado. Op. cit., p.151.

${ }^{9}$ COSTA, Maria Isabel Pereira da. "A Responsabilidade Civil dos Pais Pela Omissão do Afeto na Formação da Personalidade dos Filhos" IN MADALENO, Rolf. MILHORANZA, Mariângela Guerreiro. “Atualidades do Direito de Família e Sucessões”. Editora Notadez. 2008, p. 274.
} 
No campo doutrinário surgiram, essencialmente, duas correntes: aqueles que entendiam ser juridicamente infundada a concessão de indenização por dano moral decorrente de abandono afetivo e os que entendiam que a reparação financeira tinha por função compensar um dano ocasionado pelo descumprimento de deveres impostos pelo ordenamento jurídico brasileiro.

Para os primeiros, não existiria nenhuma previsão legal que fundamentasse esse pedido, tendo em vista que seria completamente inviável obrigar os pais a amarem seus filhos. No entendimento desses doutrinadores, qualquer tipo de indenização nesse sentido apenas iria sepultar de vez qualquer relação entre o pai/mãe ausente e o filho abandonado. Como representante dessa corrente podemos citar Leonardo Castro que entende:

"O afeto não é decorrente do vínculo genético. Se não houver uma tentativa de aproximação de ambos os lados, a relação entre pai e filho estará predestinada ao fracasso. A relação afetuosa deve ser fruto de aproximação espontânea cultivada reciprocamente, e não de força judicial (...). Após a lide, uma barreira intransponível os afastará ainda mais, sepultando qualquer tentativa futura de reconciliação. Se a solução fosse o dinheiro, a própria pensão alimentícia atenderia ao objeto da reparação, o que não ocorre. ${ }^{10}$

A corrente contrária, por sua vez, afirma ser nítida a configuração de ato ilícito no ato abandônico, já que estariam sendo descumpridos deveres impostos pelo Estatuto da Criança e do Adolescente, pelo Código Civil e pela Constituição Federal, primordialmente, em seus artigos 226, $\S 7^{\circ}, 227$, caput e 229. Nesse sentido, destacamos Novaes:

"(...) se o pai não tem culpa por não amar o filho, o tem por negligenciá-lo. O pai deve arcar com a responsabilidade por tê-lo abandonado, por não ter convivido com o filho, por não tê-lo educado, enfim, todos esses direitos impostos pela Lei." $" 11$

\footnotetext{
${ }^{10}$ CASTRO, Leonardo. "O preço do abandono afetivo". IN Revista IOB de Direito de Família, n. 46, fev./mar. 2008, p. 20.

${ }^{11}$ NOVAES, Simone Ramalho. "Abandono moral". IN Revista da EMERJ, v. 10, n. 40, 2007. p. 44.
} 
Essa mesma cisão existente no campo doutrinário, também ocorreu no âmbito do Poder Judiciário, só nesse caso, as consequências são mais graves, pois não se trata mais de debate teórico, mas de vidas de inúmeras pessoas.

Justamente por isso, é que passaremos a analisar as primeiras decisões de juízes e tribunais a respeito do tema, até que se chegasse à primeira manifestação do Superior Tribunal de Justiça sobre a questão. 


\section{Capítulo 2- O Início das Manifestações Jurisprudenciais e a Primeira Decisão do Superior Tribunal de Justiça}

Após termos demonstrado a necessidade de uma paternidade responsável, inclusive em decorrência de uma imposição constitucional, e os papéis de protagonismo assumidos pelo cuidado e o afeto dentro da instituição familiar, passaremos para o foco deste capítulo que é uma breve análise jurisprudencial acerca do tema do abandono afetivo, a partir das primeiras decisões judiciais sobre a questão até a primeira manifestação do Superior Tribunal de Justiça a respeito do mesmo.

\section{1- O Despertar Jurisprudencial}

As demandas judiciais buscando a indenização por abandono afetivo são bem recentes no cenário jurídico brasileiro.

Os primeiros processos que tinham essa temática são do início dos anos 2000 (dois mil). Segundo Excelentíssimo Senhor Doutor Ministro Fernando Gonçalves, relator do recurso especial $\mathrm{n}^{\circ}$ 757.411-MG (2005/0085464-3), que analisaremos a posteriori, primeira oportunidade em que o Superior Tribunal de Justiça se posicionou acerca desta temática, à época do seu voto:

\footnotetext{
"A questão da indenização por abandono moral é nova no Direito Brasileiro. Há notícia de três ações envolvendo o tema, uma do Rio Grande do Sul, outra de São Paulo e a presente, oriunda de Minas Gerais, a primeira a chegar ao conhecimento desta Corte". ${ }^{12}$
}

Como se pode perceber, o tema ainda é muito novo na seara do Poder Judiciário e ainda gera muitas controvérsias jurisprudenciais.

\footnotetext{
${ }^{12}$ STJ, Recurso Especial no 757.411-MG, Rel. Min. Fernando Golçalves, Brasília, 29 nov. 2005.
} 
Embora já existam duas decisões do Superior Tribunal de Justiça sobre a indenização por abandono afetivo, uma de 2005 e outra de 2012, essas também são destoantes entre si, sendo a primeira contra essa possibilidade e a última a favor.

Da mesma forma, alguns dos principais Tribunais do país, em algum momento, já decidiram de forma a acatar a possibilidade de indenização por abandono afetivo, mas em algumas outras, afastaram tal possibilidade. Isso, sem contar as decisões de juízos singulares, que já decidiram das mais variadas formas ao redor do país.

Exatamente por esta razão e para fins de conferir uma melhor estrutura para o presente trabalho, é que dividimos o histórico jurisprudencial em dois momentos: o primeiro, a ser analisado agora, que vai das primeiras e principais decisões (favoráveis e desfavoráveis à possibilidade de indenização) dos juízes e tribunais de segunda instância até o primeiro pronunciamento do STJ, em 2005, e o segundo, que vai desta última até a nova decisão deste Tribunal Superior em maio do presente ano, perpassando pela análise das decisões dos tribunais estaduais durante esse período.

Passemos então, para análise das sentenças e acórdãos que compõem o primeiro período analisado no presente trabalho.

A primeira decisão sobre o tema em âmbito de Segunda Instância foi a Decisão do Tribunal de Justiça do Rio Grande do Sul em agosto de $2000^{13}$, in verbis:

"Ementa: INVESTIGACAO DE PATERNIDADE. DANO MORAL. Somente
acarreta condenação em dano moral se o comportamento do investigado tipifica
ato ilícito, na recusa ao reconhecimento do filho. No caso, a ação foi proposta
sete anos após o nascimento do autor, este não pode desde logo não ter sido
reconhecido pelo pai. O investigado, ao ser acionado, ante a incerteza da
paternidade, se defendeu oferecendo contestação, que foi desentranhada dos autos

${ }^{13}$ TJRS, Embargos Infringentes n ${ }^{\circ} 70000271379$, Rel. Juiz Antônio Carlos Stangler Pereira, Porto Alegre, 11 ago. 2000. 
por extemporânea, mas não deixou de comparecer a perícia, para o esclarecimento do vínculo biológico. Quanto à prova do fato social, somente foi tomado o depoimento pessoal da mãe do réu, que arrolou testemunhas, ouvidas em juízo. Ante a incerteza de ser o pai do investigante, o réu amparado em seu direito, tão-somente resistiu a paternidade investigada. Em nenhum momento processual, usou o réu expedientes de cunho protelatório, para retardar o reconhecimento da paternidade, que afinal foi declarada. (15 fls.)"

A ementa transcrita trata de uma das demandas em que mais se pleiteia a incidência do abandono afetivo, que é o reconhecimento tardio da paternidade. No caso em tela, foi entendido pelo ilustre magistrado que não seria possível atribuir ao genitor nenhum ato ilícito passível de gerar dano indenizável, não tendo litigado de má-fé no curso do processo. Dessa forma, entendeu o tribunal que se o genitor cumprira o dever legal de reconhecer a paternidade e arcar com o encargo financeiro dos alimentos, não haveria que se falar em dano moral.

Já a primeira decisão judicial brasileira de que se tem notícia que concedeu indenização por abandono afetivo foi proferida pela $2^{\mathrm{a}}$ Vara Cível da Comarca de Capão da Canoa, no Rio Grande do Sul, em 15 de setembro de 2003. ${ }^{14}$

No caso em tela, o pai havia abandonado a autora, desde o nascimento, não só materialmente, não cumprindo com o dever de alimentos, mas também psicologicamente, negando-lhe afeto, carinho e amor.

Houve a época, ação de alimentos e diversas execuções. O pai, em ação revisional, chegou a se comprometer a pagar $\mathrm{R} \$ 720,00$ (setecentos e vinte reais) e a assumir seu papel de pai, mas, novamente, não honrou com nenhuma das duas obrigações. Tal conduta acarretou em graves prejuízos à moral da filha.

\footnotetext{
${ }^{14} 2^{\text {a }}$ Vara Cível da Comarca de Capão da Canoa, Rio Grande do Sul, Processo Cível $n^{\circ}$ 1411030012032-0, Juiz Mário Romano Maggioni, Capão da Canoa, 15 set. 2003.
} 
Importante analisar, os mais diversos fundamentos levantados pelo juiz da causa, o Dr. Mário Romano Maggioni, para conceder a indenização. Então, vamos a eles:

"De se salientar que aos pais incumbe o dever de sustento, guarda, e educação dos filhos (art.22 da Lei $\mathrm{n}^{\circ}$ 8.069/90). A educação abrange não somente a escolaridade, mas também a convivência familiar, o afeto, amor, carinho, ir ao parque, jogar futebol, brincar, passear, visitar, estabelecer paradigmas, criar condições para que a criança se auto-afirme.”

As palavras precisas do ilustre julgador encontram fundamento não apenas no mencionado artigo, mas também, como já ressaltado anteriormente, no artigo 227 da Constituição.

\section{E assim prossegue o magistrado:}

"Desnecessário discorrer acerca da importância da presença do pai no desenvolvimento da criança. A ausência, o descaso e a rejeição do pai em relação ao filho recém-nascido ou em desenvolvimento violam a sua honra e a sua imagem. Basta atentar para os jovens drogados e ver-se-á que grande parte deles derivam de pais que não lhe dedicam amor e carinho; assim também em relação aos criminoso."

Da mesma forma que o nobre julgador sustenta Maria Isabel Pereira da Costa:

"O desprezo, a indiferença, a falta de afeto interferem na formação da personalidade e trazem, como consequência, a agressividade, a insegurança, a infelicidade, abuso de drogas, aumento da criminalidade, etc." ${ }^{15}$

A decisão em questão continua com o seguinte argumento:

"Por óbvio que o Poder Judiciário não pode obrigar ninguém a ser pai. No entanto, aquele que optou por ser pai- e é o caso do autor- deve se desincumbir da sua função, sob pena de reparar os danos causados aos filhos."

"A função paterna abrange amar os filhos. Portanto, não basta ser pai biológico ou prestar alimentos ao filho. O sustento é apenas uma das parcelas da paternidade. É preciso ser pai na amplitude legal (sustento, guarda, educação). Quando o legislador atribui aos pais a função de educar os filhos, resta evidente que aos pais incumbe amar os filhos. Pai que não ama filho está não apenas desrespeitando função de ordem moral, mas principalmente de ordem legal, pois não está bem educando seu filho."

Mais uma vez, nos valemos dos ensinamentos de da Costa que afirma:

"A responsabilidade não se esgota no planejamento familiar e a consciência da importância da instituição familiar. Estes são apenas pressupostos para que se

\footnotetext{
${ }^{15}$ COSTA, Maria Isabel Pereira da. Op. Cit., p. 275
} 
exerça a paternidade/maternidade cumprindo com as obrigações materiais e morais para com os filhos para propiciar o seu desenvolvimento normal. Por isso é necessário que se destinem não apenas os recursos materiais para criar e educar os filhos, como também o respeito pela dignidade da pessoa do filho" 16

Pelos motivos que acabamos de expor, a sentença condenou o pai ao pagamento de $\mathrm{R} \$ 48.000,00$ (quarenta e oito mil reais), tendo transitado em julgado, tendo em vista que o réu foi revel e não recorreu da decisão.

Vale salientar, que o Ministério Público, no caso, se posicionou pela extinção da ação, defendendo a tese de que não caberia ao Judiciário condenar alguém ao pagamento de indenização por falta de amor para com o outro.

Outra decisão de juiz singular a ser pioneira na concessão de dano moral em razão de abandono afetivo foi a da $31^{\mathrm{a}}$ Vara Cível Central da Comarca de São Paulo, proferida pelo Juiz de Direito Luís Fernando Cirillo. 17

No referido processo o pleito autoral era o pagamento das despesas que a autora tivera com tratamento médico psiquiátrico, visando suprir a dor causada pela ausência paterna, além do dano moral. No caso, o réu e genitor da autora, abandonou o lar enquanto a mesma era recém-nascida. Ao longo dos anos o réu negligenciou a própria filha e recusou-se a manter qualquer contato com ela, que pertencente à mesma colônia judaica, na qual se encontravam frequentemente.

Refutando o entendimento da grande maioria dos tribunais até o momento, entendeu o ilustre magistrado que:

\footnotetext{
"Não se pode rejeitar a possibilidade de pagamento de indenização do dano decorrente da falta de afeto simplesmente pela consideração de que o verdadeiro afeto não tem preço, porque também não tem sentido sustentar que a vida de um ente querido, a honra e a imagem e a dignidade de um ser humano tenham preço, e nem por isso se nega o direito a obtenção de um benefício econômico em

${ }^{16}$ Ibdi, p. 274

${ }^{17} 31^{\mathrm{a}}$ Vara Cível Central da Comarca de São Paulo, Processo Cível nº 583.00.2001.036747-0, Juiz Luís Fernando Cirillo, São Paulo, 05 jun. 2004.
} 
contraposição à ofensa praticada contra esses bens. A paternidade provoca o surgimento de deveres."

Dessa forma, segundo o ilustre juiz do caso em tela, não haveria fundamento jurídico para concluir que não existe dever do pai de estabelecer um mínimo de relacionamento afetivo com o filho. E, da mesma maneira, a ofensa à integridade psíquica decorrente do crescimento sem o afeto paterno seria também ofensa ao princípio da dignidade da pessoa humana. Podemos destacar o trecho:

“A par da ofensa à integridade física (e psíquica) decorrente de um crescimento desprovido do afeto paterno, o abandono afetivo se apresenta também como ofensa à dignidade da pessoa humana, bem jurídico que a indenização do dano moral se destina a tutelar."

Complementando esse entendimento podemos trazer os dizeres de Marília Campos e Antônio Carlos Mathias Colto:

“(...) o cuidado se expressa predominantemente por duas formas: como um modo de sobrevivência e como uma expressão de interesse e carinho. Corolário disso é o fato de que resgatar o cuidado em cada um de nós, seres humanos, é vital no momento atual, devendo ser um imperativo moral, inserido no projeto constitucional de realização pela da dignidade humana". ${ }^{18}$

Analisando as peculiaridades do caso concreto, percebemos que foi alegado pelo genitor que após a separação do casal a mãe da autora teria criado obstáculos ao relacionamento do pai com a filha. Entendeu o magistrado, contudo, que os referidos obstáculos ao convívio do pai com a filha foram os corriqueiros de qualquer separação e que não se pode considerar que "os atritos corriqueiros nas separações conjugais recentes justifiquem que pelo resto da vida um pai se considere desobrigado de manter qualquer relação afetiva com sua filha.”.

No referido caso foi ouvida perita sobre a condição emocional da autora para se analisar o quanto a ausência do pai pode ter violado sua integridade psíquica. A perita relatou que o conflito emocional causado pela rejeição do pai biológico sob a alegação de que "pai é quem cria" e, ao mesmo tempo, a rejeição por parte do padrasto, que entendia que o pai dela

\footnotetext{
${ }^{18}$ CAMPOS, Marília. COLTO, Antonio Carlos Mathias. "Cuidando do Cuidado". IN PEREIRA, Tânia da Silva. OLIVEIRA, Guilherme de. "Cuidado \& Vulnerabilidade". Editora Atlas S.A. São Paulo. 2009.
} 
era o biológico, fora um fator de relevância suficiente para embasar a tese autoral.

O magistrado concluiu explicitando que o papel de reparar danos psicológicos era certamente do psicólogo, mas que o juiz não poderia se escusar de conferir a tutela jurisdicional pleiteada "sob pena de se negar também a possibilidade de reparação do dano moral decorrente da perda de um ente querido", dentre outras possibilidades já consagradas pelo direito pátrio.

No Tribunal de Justiça do Rio de Janeiro, por sua vez, em decisão de setembro de 2004, restou decidido pela improcedência de pedido de indenização por dano moral causado por abandono afetivo. Neste acórdão, o relator posicionou-se veemente contra tal possibilidade por entender ser "uma gananciosa pretensão oportunista, com o claro objetivo de lucro fácil, na esteira da chamada indústria do dano moral, agora com uma nova e perigosa ramificação", cuja ementa:

“Ementa: ACAO DE INDENIZACAO. RELACAO DE AFETIVIDADE.

1. Indenização. 2. Dano Moral. 3. Objetivo indenizatório deduzido por filha contra o pai, visando compensação pela ausência de amor e afeto. 4. Ninguém está obrigado a contemplar quem quer que seja com tais sentimentos. 5. Distinção entre o direito e a moral. 6. Incidência da regra constitucional, pilar das democracias do mundo a fora e a longo do tempo, esculpida no art. $5^{\circ}$, II, de nossa Carta Política, segundo a qual "Ninguém será obrigado a fazer ou deixar de fazer alguma coisa senão em virtude de Lei". 7. Pretensão manifestamente mercantilista, deduzida na esteira da chamada indústria do dano moral, como sempre protegida por deferimento de gratuidade de justiça. 8. Constatação de mais uma tentativa de ganho fácil, sendo imperioso evitar a abertura de larga porta com pretensões do gênero. 9. Sentença que merece prestígio. 10. Recurso Improvido."

No referido julgamento pode-se destacar os argumentos do ilustre relator que explicitou a diferença entre normas jurídicas e normas morais, entendendo que a pretensão autoral não tem fundamento jurídico, por mais reprovável que fosse a conduta do réu no plano moral. 
Ressaltou que não há norma jurídica cogente que ampare a pretensão autoral e que a questão situa-se exclusivamente no campo da moral. O direito apenas impõe ao pai o dever de assistência material, não podendo obrigá-lo a conceder amor ou afeto.

Afirmou ainda que: "Não há amparo legal, por mais criativo que possa ser o julgador, que assegure ao filho indenização por falta de afeto e carinho".

Remeteu-se também, aos argumentos do juiz de $1^{\circ}$ grau, transcrevendo-os:

“(...) o Poder Judiciário não pode exigir do réu- e nem de ninguém- que demonstre amor e carinho pelo semelhante. A ausência do amor paterno não vai além de mero aborrecimento não indenizável (...)”

E finalizou com os seguintes termos:

"Se assim não fosse, estar-se-ia abrindo uma larga porta de incentivo às aventuras mercantilistas do gênero, sendo previsível nova enxurrada de processos em que um dos cônjuges venha a pretender do outro, em razão da separação do casal, compensação financeira pelas juras de amor desde a fase de namoro."

"Quem sabe o traficante de drogas fracassado ou preso não arrisque obter indenização dos parentes, aos quais certamente atribuiria a culpa por desvio de conduta".

Ainda no campo das decisões que denegam a concessão de indenização por dano moral afetivo, podemos analisar outra decisão do Tribunal de Justiça do Rio Grande do Sul, em Agosto de 2005: "Ementa: APELAÇÃO CÍVEL. DANOS MORAIS. FALTA DE
RECONHECIMENTO ESPONTÂNEO DA PATERNIDADE.

Embora, em tese, viável, em condições muito específicas, a contemplação do dano extrapatrimonial no âmbito das relações familiares, deve a jurisprudência agir com extrema parcimônia na análise dos casos em que se dá semelhante postulação, sob pena de que a excessiva abertura que possa ser concedida venha a gerar enxurradas de pretensões ressarcitórias, com a total patrimonialização das relações afetivas. Caso em que não configura hipótese que justifique a concessão do pleito reparatório. Negam Provimento." 19

No presente postula-se a indenização por danos morais com base na falta de reconhecimento espontâneo da paternidade. Alega a parte autora

\footnotetext{
${ }^{19}$ TJRS, Apelação Cível no 70011681467, Rel. Des. Luiz Felipe Brasil Santos, Porto Alegre, 10 ago. 2005
} 
que a negligência do réu em deixar de reconhecer a paternidade no menor, embora sabendo ser pai do mesmo, causou grande desgaste emocional à criança.

O egrégio Tribunal entendeu que embora viável, em condições muito específicas, a contemplação do dano extrapatrimonial no âmbito das relações familiares, os julgadores deveriam agir com grande cautela, sob pena de causar posteriormente grande demanda de pretensões ressarcitórias, gerando a "total patrimonialização das relações afetivas". Nesse sentido, entendeu que o caso em tela não fazia jus a tal indenização por ter sido o réu diligente durante o processo de investigação de paternidade e ter se prontificado a estabelecer laços com o menor.

\section{2- O Primeiro Grande Julgado}

O primeiro caso a ser julgado favoravelmente em sede de segunda instância e, posteriormente, chegar ao egrégio Superior Tribunal de Justiça e, com isso, ganhar grande repercussão foi o processo iniciado na $19^{\mathrm{a}}$ Vara Cível da Comarca de Belo Horizonte o qual indeferiu o pleito autoral.

O caso em tela versa sobre a alegação de abandono afetivo do autor quando, ainda criança, seus pais se separaram e seu genitor constituiu nova família. Alega que lhe foi negado não só o convívio e relações afetivas com o pai, mas também com a própria irmã, que nascera do segundo casamento do réu.

O réu, em sua defesa, alega que foram diversas as tentativas de reaproximação com o filho, mas que a mãe do autor colocava obstáculos à convivência dos dois e, além disso, as viagens que fazia impediam o contato frequente com o filho, o que ocorria por telefone. 
Como já salientado, o juízo a quo entendeu improcedente o pedido autoral por "não haver estabelecido o laudo psicológico exata correlação entre o afastamento paterno e o desenvolvimento de sintomas psicopatológicos pelo autor", entendendo não existirem provas do dano sofrido.

Inconformado o autor interpôs Apelação e o caso foi levado ao Tribunal de Justiça de Minas Gerais, cujo julgamento ocorreu em abril de 2004, in verbis:

"Ementa: - INDENIZAÇÃO DANOS MORAIS - RELAÇÃO PATERNOFILIAL - PRINCÍPIO DA DIGNIDADE DA PESSOA HUMANA - PRINCÍPIO DA AFETIVIDADE

A dor sofrida pelo filho, em virtude do abandono paterno, que o privou do direito à convivência, ao amparo afetivo, moral e psíquico, deve ser indenizável, com fulcro no princípio da dignidade da pessoa humana". ${ }^{20}$

O referido Tribunal entendeu por bem em reformar a decisão de primeira instância para conceder a indenização por dano moral no valor de $\mathrm{R} \$ 44.000,00$, entendeu restar configurado nos autos o dano decorrente do abandono afetivo. Nesse sentido, ressaltou o ilustre Relator:

“A relação paterno-filial em conjugação com a responsabilidade possui fundamento naturalmente jurídico, mas essencialmente justo, de se buscar compensação indenizatória em face de danos que pais possam causar a seus filhos, por força de uma conduta imprópria, especialmente quando a eles é negada a convivência, o amparo afetivo, moral e psíquico, bem como a referência paterna ou materna concretas, acarretando a violação de direitos próprios da personalidade humana, magoando seus mais sublimes valores e garantias, como a honra, o nome, a dignidade, a moral, a reputação social, o que, por si só, é profundamente grave."

Foi observado, ainda, que as relações familiares mudaram com o tempo, não podendo mais ser entendida como relação de poder ou dominação, devendo ser vista como relação afetiva.

Nesse sentido, explicita o papel do princípio da dignidade da pessoa humana no campo das relações familiares:

\footnotetext{
${ }^{20}$ TJMG, Apelação Cível no 208.550-5, Rel. Des. Unias Silva, Belo Horizonte, 01 abr. 2004.
} 
"No que respeita à dignidade da pessoa da criança, o artigo 227 da Constituição expressa essa concepção, ao estabelecer que é dever da família assegurar-lhe "com absoluta prioridade, o direito à vida, à saúde, à alimentação, à educação, ao lazer, à profissionalização, à cultura, à dignidade, ao respeito, à liberdade e à convivência familiar e comunitária", além de colocá-la "à salvo de toda forma de negligência, discriminação, exploração, violência, crueldade e opressão". Não é um direito oponível apenas ao Estado, à sociedade ou a estranhos, mas a cada membro da própria família."

Conclui o nobre julgador que a responsabilidade decorrente do poder familiar não se pauta tão-somente no dever alimentar, mas também em garantir o desenvolvimento saudável da criança, respeitando a sua dignidade.

Além disso, no caso em tela, foi feito estudo psicológico nos autos e constatado que "o afastamento entre pai e filho transformou-se em uma questão psíquica de difícil elaboração" para o autor.

Com base nesses fundamentos, como mencionado anteriormente, a decisão de primeiro grau foi reformada para conceder a indenização por danos morais ao autor.

Essa decisão do Tribunal de Justiça de Minas gerou grande repercussão também na doutrina, que mais uma vez não foi uníssona na sua visão com relação ao posicionamento adotado no acórdão.

Maria Berenice Dias, por exemplo, analisou a decisão da seguinte maneira:

"Imperioso reconhecer o caráter didático dessa nova orientação, despertando a
atenção para o significado do convívio entre os pais e filhos. Mesmo que os
genitores estejam separados, a necessidade afetiva passou a ser reconhecida como
bem jurídico tutelado. (...) mesmo que o pai só visite o filho por medo de ser
condenado a pagar uma indenização, isso é melhor do que gerar no filho o
sentimento do abandono. Ora, se os pais não conseguem dimensionar a
necessidade de amar e conviver com os filhos que não pediram para nascer,
imperioso que a justiça imponha coactamente essa obrigação". ${ }^{21}$
O mesmo posicionamento não foi adotado por Anderson Schreiber que demonstrou grande temor com o teor da decisão:

\footnotetext{
21 DIAS, Maria Berenice. "Manual de Direito das Famílias". 6a edição. Editora Revista dos Tribunais, 6 a edição, São Paulo, 2010, p. 454-455.
} 
"O acórdão gera inevitável preocupação com os contornos da tutela de valores existenciais, e causa receio, seja no que tange à adoção, implícita, de um dever de amar, incompatível com qualquer acepção do sentimento, seja no que tange à identificação expressa de um dano jurídico decorrente do desamor-e, coerentemente, também do amor excessivo, do amor contido, do amor fugaz e assim por diante". ${ }^{22}$

Como suprainformado, esse caso apreciado pelo Tribunal de Justiça de Minas Gerais chegou ao Superior Tribunal de Justiça através de um recurso especial interpostos pelo pai condenado a reparar o dano afetivo que ocasionou ao filho.

O Excelentíssimo Ministro Fernando Gonçalves, relator do caso, iniciou o seu voto ressaltando que a questão é bastante polêmica e que para enfrentá-la, é necessária adentrar na delicada seara da análise de "quais danos extrapatrimoniais" seriam situações "passíveis de reparação pecuniária". Afirmando ainda, que a noção de dano vive em constante renovação, seguindo a dinâmica das mudanças sociais e que aquilo que hoje pode ser considerado apenas um aborrecimento, em um momento posterior pode ser tratado como algo que merece a tutela do Judiciário.

Prosseguiu com sua análise observando a tese de dois doutrinadores que defendiam a finalidade punitiva e dissuasória da indenização por abandono afetivo, na qual destacamos a tese relatada de Cláudia Maria da Silva:

"Não se trata, pois, de "dar preço ao amor"- como defendem os que resistem ao
tema em foco- tampouco de "compensar a dor" propriamente dita. Talvez o
aspecto mais relevante seja alcançar a função punitiva e dissuasória da reparação
dos danos, conscientizando o pai do gravame causado ao filho e sinalizando para
ele, e outros que sua conduta deve ser cessada e evitada, por reprovável e grave".
23

Sustentou em suma explanação, no argumento de que a legislação pátria já prevê, no caso de descumprimento injustificado do dever de sustento ou de abandono, tanto o Estatuto da Criança e do Adolescente,

\footnotetext{
${ }^{22}$ SCHEREIBER, Anderson. "Novas tendências da responsabilidade civil brasileira". IN: "Revista Trimestral de Direito Civil, v.22, abr./jun.2005, p.62-63.

${ }^{23}$ SILVA, Claudia Maria da. "Descumprimento do Dever de Convivência Familiar e Indenização por Danos á Personalidade do Filho". IN Revista Brasileira de Direito de Família, Ano VI, n 25Ago-Set 2004)
} 
quanto o Código Civil, nos seus artigos 24 e 1638, II, respectivamente, a sanção da perda do poder familiar. Para ele, tal sanção já cumpriria de forma satisfatória e ampla, ambas as funções (punitiva e dissuasória) da indenização pelo abandono moral.

Ademais, destacou que a condenação do pai a pagar uma indenização ao filho, certamente, iria sepultar toda e qualquer chance de uma reaproximação deles no futuro, impedindo que o filho se visse acolhido em algum momento pelo amor paterno.

Por fim, encerrou o seu voto da seguinte forma:

"Desta feita, como escapa ao arbítrio do Judiciário obrigar alguém a amar, ou a manter um relacionamento afetivo, nenhuma finalidade positiva seria alcançada com a indenização pleiteada."

Esse posicionamento do Superior Tribunal de Justiça suscitou diferentes opiniões na doutrina especializada, dentre as quais destacamos a crítica feita por Rodrigo da Cunha Pereira, advogado que patrocinou a referida demanda, que afirmou que a decisão do Tribunal de Justiça de Minas foi indevidamente cassada, "sob a equivocada argumentação de que a "punição" para o pai que abandona um filho é a destituição do poder familiar". Ressaltou ainda que:

\begin{abstract}
"A imputação da perda do poder familiar como pena para aquele que abandona seu filho serviria somente em prêmio para o genitor abandônico, ou mesmo de estímulo para aqueles que não querem ser responsabilizados pelo ato de gerar um filho. (...) Certamente um filho que precisou recorrer à justiça para pedir ao Estado-Juiz uma reparação civil, já sabe que se antes já não tinha seu pai por perto, com a condenação ele se afastará ainda mais". ${ }^{24}$
\end{abstract}

Como vimos a questão da indenização por abandono afetivo começou a ser discutida na época e mostrava-se, o que podemos perceber ainda hoje, ser bastante controversa.

É mister salientar que no referido julgamento no STJ foram defendidas ambas as posições, existindo posicionamento contrário ao que saiu vencedor. Nesse sentido, vemos o voto vencido do Ministro Barros

\footnotetext{
${ }^{24}$ PEREIRA, Rodrigo da Cunha. Op. Cit.
} 
Monteiro, que entendeu existir sim uma conduta ilícita que embasaria o dano moral indenizável, visto que existiria a conduta ilícita, o dano e o nexo de causalidade:

"Penso que daí decorre uma conduta ilícita da parte do genitor que, ao lado do dever de assistência material, tem o dever de dar assistência moral ao filho, de conviver com ele, de acompanhá-lo e de dar-lhe o necessário afeto."

Ressalta, ainda, o Ministro que a sanção de perda do poder familiar, que poderia incidir sobre o réu, em nada interfere o julgamento da existência ou não do dano moral, assim:

"Penso também, que a destituição do poder familiar, que é uma sanção do Direito
de Família, não interfere na indenização por dano moral, ou seja, a indenização é
devida além dessa outra sanção prevista não só no Estatuto da Criança e do
Adolescente, como também no Código Civil anterior e no atual."

Feita esta análise dos primeiros pronunciamentos da jurisprudência sobre a questão, podemos perceber que desde os primeiros passos dentro do cenário jurídico brasileiro, esta sempre foi bastante polêmica e difícil solução.

Podemos perceber ainda, dentre as mais diferentes posições, que existia uma grande preocupação dos juízes e tribunais com as consequências que poderiam advir da possibilidade do judiciário reconhecer a obrigação de reparação por abandono afetivo dos pais para com os filhos, principalmente, com a hipótese de o Judiciário ser assolado com uma enxurrada de ações referentes ao tema.

Dito isto, é fundamental que passemos a análise de como essa primeira decisão do Superior Tribunal de Justiça influenciou as decisões posteriores dos Tribunais de segunda instância dos Estados e como se deu essa trajetória da jurisprudência até a segunda decisão do tribunal superior ocorrida no ano de 2012. É dessa tarefa, que nos encarregaremos no próximo capítulo. 


\section{Capítulo 3- O Reflexo da Posição do STJ Sobre os Tribunais de Justiça: A Sombra de uma Decisão}

A decisão supra-analisada foi primordial para a temática do abandono afetivo. Se antes da primeira decisão do Superior Tribunal de Justiça essa era uma questão muito pouco debatida e difundida no direito brasileiro, após a prolação da mesma, o assunto veio à tona com muito mais força no cenário jurídico.

Conforme já foi frisado em momento anterior, a decisão em tela trouxe grande divergência na doutrina, impulsionando assim, uma série de estudos e trabalhos acerca do tema. Deste momento em diante, o que se viu foi uma série de questionamentos e análises por parte de juristas e psicólogos sobre os possíveis erros e acertos desta decisão e até que ponto seria possível cobrar dos pais determinadas condutas.

Contudo, não foi apenas entre os especialistas que a possibilidade de indenização por abandono moral ganhou relevo. Após a grande repercussão do pioneiro (em sede superior) caso apreciado pelo STJ, houve uma percepção por parte das pessoas de que uma nova possibilidade de reparação estava sendo colocada em pauta e inúmeros casos semelhantes ao julgado começaram a vir à tona para a apreciação do Poder Judiciário.

Antes de 2005, pouquíssimas demandas sobre essa nova possibilidade de indenização haviam sido analisadas por juízes e Desembargadores, mas desde então houve um grande crescimento com relação a esse tipo de demanda. Tal crescente fez surgir um novo desafio, de grande complexidade e bastante delicado, para os julgadores brasileiros.

Embora a decisão capitaneada pelo Ministro Fernando Gonçalves tenha sido no sentido de não admitir a referida reparação, muitas outras ações foram impetradas visando melhor sorte na tentativa de buscar um 
alento para seus anseios, talvez impulsionadas pela divergência entre os juízos singulares, tribunais e até Ministros do STJ, quando da análise do Recurso Especial no 757.411-MG.

Diante de um número cada vez maior de demandas, era mais do que esperado que a jurisprudência também não alcançasse uma unanimidade.

Entretanto, embora no Brasil o sistema adotado seja o romanogermânico, no qual a jurisprudência não é a principal fonte de direito a ser observada pelos magistrados, é evidente que entendimento adotado por um tribunal superior tem grande peso e influência sobre os tribunais estaduais. E foi exatamente esse cenário que se constituiu. A maioria dos casos que foram julgados desde então, também denegaram a possibilidade de indenização por abandono afetivo, se valendo de inúmeros argumentos diferentes, mas, praticamente todos tiveram como um dos argumentos balizadores a jurisprudência do STJ.

Porém, como uma quantidade de processos muito maior do que se tinha anteriormente, e com uma significativa parte da doutrina se manifestando de maneira favorável à possibilidade de indenização, era previsível que também surgissem decisões que se filiassem a tal entendimento.

Desta forma, em praticamente todos os principais Tribunais de Justiça do país, passaram a existir decisões que se colocavam de forma contrária ao posicionamento jurisprudencial majoritário.

Perante esse panorama, nada mais prudente do que destacarmos alguns dos julgados proferidos por determinados tribunais de justiça brasileiros e os valores e fundamentos que foram analisados em cada um deles.

Inicialmente, cabe destacar três acórdãos provenientes do Tribunal de Justiça do Rio Grande do Sul, um desfavorável e dois favoráveis à 
possibilidade de indenização em voga, tendo em vista que este é, provavelmente, o Estado brasileiro em que mais foram propostas demandas pleiteando indenizações por abandono afetivo.

O primeiro dos referidos acórdãos é fruto de um julgamento em 13/10/2011, no qual o egrégio Tribunal, representado pela Oitava Câmara Cível, entendeu pela impossibilidade da indenização, conforme se verifica abaixo:

"Ementa: APELAÇÃO CÍVEL. INDENIZAÇÃO POR DANO MORAL AOS FILHOS. ABANDONO AFETIVO. No direito de família, o dano moral é, em tese, cabível. No entanto, imprescindível que haja a configuração do ato ilícito. O distanciamento do varão em relação aos filhos não constitui motivo para fundamentar a indenização por dano moral, sendo tal fato um acontecimento bastante recorrente, um fato da vida, apesar de lamentável. Embora seja plausível que os apelantes tenham sofrido pela ausência do pai, essa situação não pode ser atribuída ao genitor somente, a ponto de levar à obrigação de indenizar. Ademais, em que pese reprovável, a conduta do demandado não se enquadra no conceito jurídico de ato ilícito, que gera o dever de indenizar. NEGARAM PROVIMENTO. UNÂNIME." 25

No referido caso, os autores interpuseram recurso ao TJRS para tentar reformar a sentença de primeiro grau, que não deu provimento ao pedido de indenização por abandono afetivo.

Alegaram os recorrentes que sendo o genitor dos menores, o causador de tanta dor pelo abandono, não há motivos para não responsabilizá-lo e que o dano não é apenas o conjunto dos prejuízos financeiros ou patrimoniais. Salientaram, ainda, que os apelantes necessitam de tratamento psicológico, a fim de que possam crescer saudáveis e se consiga minorar os efeitos do abandono.

Pela simples leitura da ementa transcrita é possível perceber que, julgou o Tribunal à época, por unanimidade, que não era cabível a indenização por dano moral decorrente de abandono afetivo, entendendo que o sofrimento causado pela conduta do pai, ainda que reprovável, não se

\footnotetext{
${ }^{25}$ TJRS, Apelação Cível no 70044172401, Oitava Câmara Cível, Rel. Des. Luiz Felipe Brasil Santos, Porto Alegre, 13 de out. 2011.
} 
enquadra no conceito jurídico de ato ilícito, o que ensejaria o dever de indenizar.

Nesse sentido, destacamos do voto do ilustre relator Luiz Felipe Brasil Santos o trecho:

\begin{abstract}
"Não se está, por óbvio, minimizando o sofrimento dos menores, porém, o fato de ter ocorrido a separação do casal e com isso, o afastamento deliberado do varão da companhia dos filhos, não se constitui motivo que enseje uma indenização por dano moral, pois ato ilícito, efetivamente, não se constituiu. Ademais, quando a genitora dos menores engravidou de Lorenzo, já era do seu conhecimento a distância geográfica entre os infantes e o genitor. Aliás, provavelmente, já deveria ser do seu conhecimento a distância afetiva, com o fim do relacionamento conjugal, que era próximo, ou mesmo que já havia terminado."
\end{abstract}

No voto em questão, o relator manteve o mesmo entendimento que já havia adotado na Apelação Cível no 70011681467, em abril de 2004, que já foi objeto de análise, no presente trabalho, em momento anterior.

Todavia, interessante notar que, na obra "Pais, Filhos e Danos", o Excelentíssimo Desembargador, já havia se manifestado de forma distinta ao lecionar que:

\begin{abstract}
"Neste contexto, a ausência injustificada do pai origina evidente dor psíquica e consequente prejuízo à formação da criança, decorrente da falta não só do afeto, mas do cuidado e da proteção (função psicopedagógica) que a presença paterna representa na vida do filho, mormente quando entre eles já se estabeleceu um vínculo de afetividade (como no caso em comento, em que o filho foi abandonado aos seis anos de idade). E, além da inquestionável concretização do dano, também se configura, na conduta omissiva do pai, a infração aos deveres jurídicos de assistência imaterial e proteção que lhe são impostos como decorrência do poder familiar". ${ }^{26}$

O nobre magistrado registrou ainda, no mesmo trabalho jurídico, que se o Judiciário, por diversas vezes, concedia indenizações por dano moral em situações como negativação de nome, que seria muito menos grave do que o ato de abandonar afetivamente um filho, então o mesmo não poderia se furtar de reparar o dano causado por um desamparo emocional. E nessa colocação, inclusive, é inteiramente acompanhado por Andrekowisk, que
\end{abstract} assim se manifesta:

\footnotetext{
26 SANTOS. Luiz Felipe Brasil. "Pais, Filhos e Danos". Disponível em:
} http://direitodefamiliars.blogspot.com.br/2011/06/doutrina-pais-filhos-e-danos.html 
"É notório que hoje muitos arrepiam-se diante dos pedidos de indenização por dano moral, posto que vem ocorrendo uma banalização deste instituto, pois qualquer abalo psicológico tem sido motivo de pleitos na justiça, com pedidos de indenizações milionárias. Apesar de toda a oposição doutrinária, atualmente os tribunais têm decidido no sentido de condenar ao pagamento de indenização por dano moral por simples negativação nos cadastros de inadimplentes, objetivando coibir essa prática, quando indevida. Com efeito, é incontroverso que os prejuízos causados dentro do Direito de Família são muito mais danosos que àqueles, posto que o cometimento de atos ilícitos na seara familiar acarreta prejuízos morais na maioria das vezes irreversíveis, uma vez que afetam o direito da personalidade, dignidade das pessoas, motivo pelo qual não merecem ser apreciadas com o preconceito decorrente das inúmeras ações fundadas em meros abalos de crédito." 27

E por fim, mas não menos importante, Luiz Felipe Brasil Santos também destacou a importância das decisões judiciais diante da questão, ao afirmar que:

"Nessa perspectiva, sobressai a atuação da jurisprudência na aplicação integrativa dos princípios constitucionais - em especial o da dignidade da pessoa humana como forma de não deixar recair exclusivamente sobre a vítima as consequências do dano."

Porém, como se pode perceber diante dos dois julgados no qual o ilustre Desembargador foi relator, embora reconheça a possibilidade de indenização por abandono afetivo, o mesmo, na prática, acabou por se filiar a corrente jurisprudencial majoritária, tanto no Rio Grande do Sul, como no restante do país.

Ainda analisando as decisões do mesmo tribunal, destacamos a primeira das decisões pró-ressarcimento por abandono moral a serem abordadas.

A primeira decisão que analisaremos foi prolata em 29 de novembro de 2007, confirmando em parte a sentença do Juízo de primeiro grau para condenar o réu ao pagamento de indenização por danos morais decorrente de abandono afetivo. Curiosamente, esta decisão também foi proferida pela Oitava Câmara Cível, porém, ela é cronologicamente anterior à decisão suprassublinhada.

\footnotetext{
${ }^{27}$ ANDREKOWISK, Lauane Gomes Braz. Dano moral nas ações de filiação. Revista de Direito Privado, n. 25, jan./mar. 2006, p. 182.
} 
"Ementa: APELAÇÃO CÍVEL. INDENIZAÇÃO DANOS MATERIAIS E MORAIS. ABANDONO DO FILHO. FALTA DE AMPARO AFETIVO E MATERIAL POR PARTE DO PAI. HONORÁRIOS ADVOCATÍCIOS. REDIMENCIONAMENTO.

A responsabilidade civil, no Direito de Família, é subjetiva. O dever de indenizar decorre do agir doloso ou culposo do agente. No caso, restando caracterizada a conduta ilícita do pai em relação ao filho, bem como o nexo de causalidade e o dano, cabe indenização por danos materiais e morais.

Nas demandas condenatórias, a verba honorária deve incidir sobre o valor da condenação. Inteligência do art. $20, \S 3^{\circ}$, do CPC. RECURSO DO AUTOR PARCIALMENTE PROVIDO. APELAÇÃO DO
REQUEIRDO IMPROVIDO." ${ }^{28}$

$\mathrm{Na}$ lide em ressalto, a sentença a quo condenou o réu ao pagamento da indenização por danos morais ao seu filho, que, inconformado, interpôs Apelação ao Tribunal alegando que seria injusta e desproporcional a sua condenação, dada ausência dos requisitos legais que configuram o dever de indenizar, destacando, nesse sentido, decisão proferida pelo Superior Tribunal de Justiça, cujo teor já fora analisado.

Como vimos, entendeu o Tribunal nessa ocasião que era cabível a indenização, nos termos do voto do ilustre relator Claudir Fidélis Faccenda, in verbis:

"É perfeitamente possível o filho buscar reparação pecuniária do pai por danos morais, em casos onde há a efetiva comprovação de que houve negativa de amparo afetivo, moral e psicológico de que toda criança necessita. A violação dos direitos à personalidade do filho, como a honra, a imagem, dignidade e a reputação social, é passível de reparação no âmbito da responsabilização civil e assegurada pela Constituição Federal (art. 5, inc. X)."

$(\ldots)$

"Desse modo, pelo menos em tese, viável a contemplação do dano extrapatrimonial no âmbito das relações familiares. Contudo, a jurisprudência deve agir com extrema cautela, sob pena de gerar uma total monetarização das relações afetivas.”

Observa-se, no voto do relator que, embora o mesmo tenha frisado a possibilidade da "reparação pecuniária" e a concedido no caso concreto,

\footnotetext{
${ }^{28}$ TJRS, Apelação Cível no 70021427695, Rel. Des. Claudir Fidélis Faccenda, Porto Alegre, 29 nov. 2007.
} 
este possui grande preocupação com a possibilidade de ocorrer um processo de monetarização do afeto, caso a jurisprudência não seja cautelosa.

Com a mesma preocupação do magistrado, mas de forma muito mais incisiva, manifesta-se Ivone M. Candido Coelho de Souza:

\begin{abstract}
"A família, desfigurada no projeto parental, se contorce premida por sentimentos de fracassos, invejas, revanches e crueldades. Frágil, ao sustentar a estabilidade mental do filho que não pode proteger, recorre aos tribunais para que, dimensionando a extensão dos lanhos afetivos, coloque um preço sobre as fugas, para que determine multas sobre as perdas. É preciso avaliar com cuidado e sensibilidade interdisciplinares as dolorosas e arriscadas ausências, de todos os jeitos, antes de imputar a um genitor, simplesmente, as culpas que serão convertidas em valores econômicos."
\end{abstract}

"Monetarizar abandonos, pobreza amorosa, modelos não acessíveis ou precariedade do exercício previsto muitas vezes de forma idealizada e, portanto, acima das capacidades disponíveis, longe de ser um instrumento de aquisição ao interesse do filho, pode ao contrário, redundar em novas erupções dentro do quadro já instabilizado." 29

Por outro lado, Flávio Tartuce afasta prontamente a importância dessa discussão sobre se dar preço ao afeto:

“Ato contínuo de análise, não é pertinente voltar ao debate, já superado quando da discussão da própria existência do dano moral como dano reparável, sobre a monetarização do afeto. Em verdade, a indenização por dano moral, o que inclui a hipótese de abandono afetivo, tem o condão de reparar um sofrimento suportado pela vítima. Em suma, o valor pago tem um intuito compensatório, no sentido de ser um derivativo do ato prejudicial praticado por outrem.",30

Retornando ao voto analisado, foi grifada ainda, a necessidade de que seja evidenciado o agir com dolo ou culpa para restar caracterizada a ilicitude da conduta, surgindo, assim, o dever de indenizar.

O Desembargador citou, também, a sentença prolatada pelo Juiz de primeiro grau Eduardo Furian Pontes, para demonstrar seu ponto de vista de que a sociedade e o direito estão em constante mudança e que, hoje, entende-se como família a comunidade afetiva onde o carinho, a atenção e o respeito tornam-se imprescindível para sua subsistência.

\footnotetext{
${ }^{29}$ SOUZA. Ivone M. Candido Coelho de. "Dano Moral por Abandono: Monetarizando o Afeto". IN Revista Brasileira de Direito de Família e Sucessões, N 13, Dez-Jan 2010.

${ }^{30}$ TARTUCE. Flávio. "Danos Morais por Abandono Moral". IN Revista Brasileira de Direito das Famílias e Sucessões. № 7. Dez-Jan 2009.
} 
No entanto, amar não seria dever ou direito no nosso ordenamento jurídico, mas sim inerente aos homens de bem e de bons costumes. $\mathrm{O}$ abandono afetivo entra na seara do direito quando são cumpridos os deveres legais do genitor para com sua prole. Nas palavras do referido magistrado de primeiro grau:

\begin{abstract}
"Seja como for, embora sentimento moral e humanitário, a falta de amor ou de afeto, não pode e não deve ser considerado ato ilícito, fugindo à seara do direto positivo. É simplesmente sentimento.

No entanto, existem deveres e direitos que resultam do vínculo familiar que podem ser cobrados independentemente do sentimento - que deveria estar presente sempre, porém não pode ser exigido judicialmente, pois o direito apenas é um degrau para chegar-se mais perto do mundo ideal - dever ser - mas há espaços inalcançáveis.
\end{abstract}

Nas relações entre pais e filhos, tanto o Código Civil anterior (art. 384. incisos I e II), como o atual (art. 1.634, incisos I e II estabelecem deveres, dentre os quais está o dever do pai e da mãe de ter o filho em sua companhia e educá-lo, o chamado dever de convivência. Da mesma forma encontramos no Estatuto da Criança e do Adolescente, em seus artigos $3^{\circ}, 4^{\circ}$ e $5^{\circ}$, o dever da família de assegurar o desenvolvimento físico, mental, moral, espiritual e social do menor, em condições de dignidade, referindo expressamente a convivência familiar como direito da criança e do adolescente e a punição em caso de omissão quanto à preservação de seus direitos da personalidade.

Nesses termos, o abandono do filho, desde que seja voluntário e injustificado, configura violação ao dever antes especificado. Conduta essa que afronta ao art. 1.634, inciso II do Código Civil. Aí residindo a ação ou a omissão, um dos requisitos da responsabilidade civil. E se dessa 'conduta' resultam danos ao filho, estarão preenchidos os outros requisitos: nexo causal e dano.

Pertinente salientar que a falta de afeto ou amor não servem de supedâneo à condenação paterna ao pagamento de indenização ao filho, mas, sim, o ato ilícito descrito nos próprios textos legais.

Com efeito, não se pode perder a técnica jurídica, mesmo diante de uma saudável interdisciplinaridade entre o direito e outras ciências ou áreas do conhecimento. Assim, enquanto na psicanálise, preponderam os aspectos psicológicos de natureza afetiva e sentimental, no âmbito jurídico os deveres e direitos são o norte, procura possibilitar o convívio em sociedade de forma disciplinada e segura, por meio do estabelecimento de deveres e direitos e suas consequências nas respectivas violações."

Na sentença proferida pelo juízo a quo, fica evidente o intuito de rebater o principal argumento da corrente contrária à possibilidade de reparação monetária por abandono moral, o de que seria impossível se penalizar um pai por desamor, já que tal ato não se configuraria como um ilícito e, portanto, não ensejaria uma indenização. 
Com base nos fundamentos acima expostos o Relator do caso julgou os valores arbitrados na sentença recorrida como suficientes, a título de indenização referente ao dano moral sofrido pelo autor.

Contudo, no caso em questão houve um voto divergente do revisor José Ataídes Siqueira Trindade, que entendeu que no caso concreto não havia sido comprovado o dano sofrido pelo autor. O Desembargador citou o artigo 186 do Código Civil, basilar da responsabilidade civil, e o art. 227 da Carta Magna, para demonstrar que o descumprimento dos deveres decorrentes do poder familiar é capaz de autorizar a reparação do ato ilícito por meio de indenizatória.

No entanto, para o Desembargador seria necessário o cumprimento de outros requisitos para a responsabilização, em suas palavras:

"Contudo, não obstante entendimento contrário, filio-me a corrente doutrinária no sentido de que não bastam condutas (ação ou omissão) que podem levar à responsabilização do seu autor. Ou seja, a ausência de afeto ou abandono emocional do pai para com o filho, não gera por si só, o dever de indenizar.

É que devem estar presentes os demais pressupostos da responsabilidade civil dano injusto, relação de causalidade, fator de atribuição, que ordinariamente é a culpa em sentido lato (...)"

Relata o Jurista que seria necessária a atuação de profissional da área de psicologia e/ou psiquiatria para que seja avaliado o grau de dano que sofreu a criança ou o adolescente em razão da omissão de afeto dos pais e o tipo de tratamento adequado. Ou seja, não bastaria a omissão do afeto e o abandono emocional, sendo essencial a demonstração do dano sofrido com a conduta do réu.

Essa mesma necessidade é abordada por Samira Skaf:

"Devido a isso é que o magistrado no julgamento do caso concreto deve minuciosamente analisar as provas periciais, testemunhais e demais laudos psíquicos, bem como as documentais a fim de proferir um veredicto justo, condizente com a verdade e com os ditames do próprio Poder Judiciário, o qual por muitas vezes é utilizado hoje como meio de litigância de má-fé e enriquecimento sem causa, desvirtuando-se, portanto de seu objetivo: dar a cada um o que é realmente seu por direito." ${ }^{, 31}$

\footnotetext{
31 SKAF, Samira. "Possibilidade Legal de Concessão de Dano Moral aos Filhos Abandonados Afetivamente pelos Pais, Frente ao Cometimento de Ato Ilícito". IN Revista Brasileira de Direito das Famílias e Sucessões. No 13. Dez-Jan 2010. Disponível em: http://www.magisteronline.com.br
} 
Alerta, ainda, o nobre julgador, que:

"Importante ressaltar, por fim, até porque a matéria é polêmica, que a necessidade de efetiva demonstração do dano - o qual não se presume - mais se justifica, na medida em que, na aplicação da responsabilidade civil no âmbito do Direito de Família, existe o perigo real de se monetizar as relações familiares.”

No mesmo sentido, o desembargador citou o autor SÉRGIO GISCHKOW PEREIRA, para reforçar esse entendimento:

"Na verdade, do erro de não querer indenizar dano moral, está se partindo para o erro oposto, constituído pelo exagero, pelo excesso, pela demasia de exigir dano moral por tudo e por qualquer motivo. Com isto, algo sublime está sendo distorcido e amesquinhado por interesses patrimoniais, monetários, materiais, puramente financeiros, com muitos tentando ganhar dinheiro a custa dos outros. Já não mais se trata do nobilíssimo exercício de cidadania e da louvável e salutar busca dos direitos em juízo. Não. A pretexto do dano moral, o que se passa a querer é obter vantagens materiais a qualquer título."

Observa-se, portanto, mais uma vez, a imensa preocupação dos magistrados e de determinados doutrinadores, sejam eles contra ou a favor desse tipo de ressarcimento, com a possibilidade das relações afetivas serem monetarizadas. Para alguns, existe um grande risco de que o que deveria ser um nobre instrumento para uma justa reparação, se torne uma imensa janela aberta, para uma busca mercantilista e infundada de vantagens patrimoniais.

Esse mesmo fundamento foi utilizado pelo pai que recorreu ao tribunal em Apelação Cível contra a sentença de primeiro grau que o condenou ao pagamento de cem salários mínimos, a título de indenização por danos morais, visto que ocorreu a revelia.

“Ementa: APELAÇÃO CÍVEL. DIREITO DE FAMÍLIA. AÇÃO DE INDENINAÇÃO POR DANOS MORAIS DECORRENTE DE ABANDONO MORAL E MATERIAL. RÉU REVEL. VERBA INDENIZATÓRIA.

1. A revelia do apelante torna desnecessária a intimação da sentença. Contra ele correrão os prazos independentemente de intimação, a partir da publicação da sentença em audiência ou em cartório, com fulcro em súmula 12 do TJRS. O início do prazo para recurso, na espécie, é a data da publicação da sentença em Cartório, não podendo o réu revel receber a benesse de ser intimado pessoalmente da sentença. Interposto o recurso fora do prazo legal, o corolário é o não conhecimento da apelação.

2. A fixação do quantum indenizatório requer prudência, pois, além de se valer para recuperar - quando é possível - o status quo ante, tem função pedagógica e compensatória, com o intuito de amenizar a dor do ofendido. 
3. É razoável o valor fixado a r.sentença, uma vez que a quantia de cem salários mínimos nacionais é suficiente, no caso concreto, para indenizar o autor do abalo injustamente sofrido pelo filho apelante.

RECURSO DO RÉU NÃO CONHECIDO E RECURSO DO AUTOR DESPROVIDO." 32

Alegou o recorrente, na ocasião, a impossibilidade de patrimonialização das relações afetivas. Assegurou inexistirem provas nos autos de que o réu pudesse ter certeza da paternidade, uma vez que o autor ingressou com a respectiva ação investigatória quando contava com onze anos de idade.

O Tribunal do Rio Grande do Sul, nessa ocasião, não foi detido por esse receio tão alardeado e decidiu, por unanimidade, em manter a decisão recorrida.

O Desembargador relator do caso analisado, Ricardo Raupp Ruschel ressaltou em seu voto que para que haja a configuração de danos morais é necessária a conduta ilícita descrita no art. 186 do CC e citou, também, o já mencionado art. 227 da Constituição Republicana para embasar o entendimento de que houve ilícito.

Destacou, da mesma forma, o art. $4^{\circ}$ do Estatuto da Criança e do Adolescente estabelece o dever da comunidade, da sociedade em geral e da família de assegurar o direito da criança à convivência familiar. Assim como, o Código Civil também prevê no art. 1.634 ser obrigação dos pais administrarem a educação e criação dos filhos, tendo-os em sua companhia, o que configura o direito à convivência familiar.

Tal posicionamento encontra amparo nos ensinamentos, do sempre preciso, Rodrigo Pereira da Cunha:

\footnotetext{
"O descumprimento do exercício do poder familiar (art. 1.634/CCB) por qualquer um dos genitores configura um ilícito, sendo, portanto, o fato gerador da indenização. Qualquer pessoa, qualquer criança, para se estruturar como sujeito e ter um desenvolvimento saudável, necessita de alimentos para o corpo e para a
}

\footnotetext{
32 TJ-RS, Apelação Cível No 70021592407, Sétima Câmara Cível, Des. Rel. Ricardo Raupp Ruschel, 14 mai 2008.
} 
alma. O alimento imprescindível para a alma é o amor, o afeto. E afeto significa afeição por alguém, dedicação. Afeiçoar significa também instruir, educar, formar, dar feição, forma ou figura. Essa é uma diferença entre afeto e amor. O afeto não é somente um sentimento, mas também uma ação". ${ }^{33}$

No entanto, ressaltou sua posição de que antes da ação de reconhecimento de paternidade não há que se falar em descumprimento dos deveres inerentes aos pais, tais como cuidar, educar e sustentar os filhos, visto que não haveria conhecimento por parte do genitor da existência da prole.

Após termos analisado os entendimentos existentes no Estado do Rio Grande do Sul, passemos então a verificar a jurisprudência do Estado de onde se originou o primeiro caso que chegou até o Superior Tribunal de Justiça, Minas Gerais.

Embora tenha sido um dos Estados pioneiros na discussão sobre o tema, Minas foi, possivelmente, um daqueles em que a posição do STJ mais conseguiu eco. Mesmo sendo territorial e demograficamente grande, foram pouquíssimas as decisões que se filiaram ao ressarcimento aqui estudado.

Justamente por isso, talvez a decisão que melhor reflita todos os posicionamentos defendidos no tribunal mineiro seja a de 09/11/2011, in verbis:

"EMENTA: DIREITO PROCESSUAL CIVIL E RESPONSABILIDADE CIVIL. INTERESSE DE AGIR. IMPOSSIBILIDADE JURÍDICA DO PEDIDO. CERCEAMENTO DE DEFESA. ABANDONO AFETIVO. DANOS MORAIS. REPARAÇÃO. LITIGÂNCIA DE MÁ-FÉ. PRELIMINARES REJEITADAS E RECURSO NÃO PROVIDO.

- É juridicamente possível o pedido que encontra amparo no direito material positivo.

- "Há o interesse de agir quando o provimento jurisdicional postulado for capaz de efetivamente ser útil ao demandante."

- A parte que não recorreu contra a decisão que indeferiu a produção de prova pericial não pode alegar cerceamento de defesa, pois precluiu o direito de produzi-la, como decorre do art. 183 do Código de Processo Civil.

\footnotetext{
${ }^{33}$ PEREIRA, Rodrigo da Cunha. Op. Cit.
} 
- O abandono afetivo não constitui ilícito passível de gerar reparação por danos morais.

- O uso dos recursos previstos no ordenamento jurídico, bem como da argumentação que a parte entende como suficiente a embasar sua pretensão não configura litigância de má-fé.

VV. EMENTA: AÇÃO DE INDENIZAÇÃO - DANOS MORAIS ABANDONO PATERNO - VIOLAÇÃO AO PRINCÍPIO DA DIGNIDADE DA PESSOA HUMANA - NOVA CONFIGURAÇÃO DA ENTIDADE FAMILIAR - DEVERES DOS PAIS - ART. 227 DA CONSTITUIÇÃO - ART. 1.634, I E II, DO CÓDIGO CIVIL. RECURSO PROVIDO

- A família atual deve se preocupar com o livre desenvolvimento da personalidade de cada um dos seus membros, sendo um ente funcionalizado, onde todos têm o objetivo de promover o livre desenvolvimento dos demais membros.

- Nesse contexto, em que a família torna-se o centro de desenvolvimento da personalidade de cada um de seus membros, a conduta do pai que abandona seu filho revela-se violadora dos seus direitos, uma vez que o art. 227 da Constituição inclui no rol dos direitos da criança e do adolescente a convivência familiar.

- O pai que deixa de prestar a assistência afetiva, moral e psicológica a um filho, violando seus deveres paternos, pratica uma conduta ilícita, ensejadora de reparação no campo moral." ${ }^{34}$

O julgado retrata a divergência acerca do tema do abandono afetivo. Percebemos no caso dois votos muito bem fundamentados em sentidos opostos.

Analisaremos primeiro o voto vencedor prolatado pelo Desembargador Relator José Flávio de Almeida, que julgou improcedente o recurso autoral e manteve a decisão do juízo a quo negando o pleito autoral e, consequentemente, a indenização por danos morais em decorrência do abandono moral.

Alega o réu que o pedido autoral é juridicamente impossível, contudo, como bem ressaltou o relator, a impossibilidade jurídica do pedido decorre da existência de vedação legal para a pretensão do autor, o que não é o caso, porque o ordenamento jurídico admite o pedido de reparação por dano moral fundada em abandono afetivo.

\footnotetext{
${ }^{34}$ TJ-MG, Apelação Cível No 1.0472.08.017785-1/001, Des. Rel. José Flávio de Almeida, Belo Horizonte, 09 nov. 2011.
} 
Apesar disso, votou o relator pela improcedência do pedido autoral, entendendo que o abandono afetivo não caracteriza ilícito passível de reparação a título de dano moral. Citou para embasar sua posição o precedente do Superior Tribunal de Justiça, como quase a totalidade dos julgados que vieram posteriormente. Em suas palavras:

“Desse modo, não se identifica prática de ato ilícito atribuível ao apelado, não se tendo configurado os requisitos necessários para lhe impor responsabilidade civil pelos supostos danos extrapatrimoniais."

Acompanhou o voto do Relator o Desembargador Alvimar de Ávila, entendendo que está fora do âmbito do judiciário resolver o problema de falta de afeto nas relações familiares. Sendo assim, esclarece que:

\begin{abstract}
"Destarte, escapa ao arbítrio do Judiciário obrigar alguém a amar ou a manter um relacionamento afetivo, sendo que, eventual deferimento do pedido não atenderia a finalidade almejada, pois o pai condenado a indenizar a filha por não the ter atendido as necessidades de afeto, não encontrará ambiente para reconstruir o relacionamento. Muito pelo contrário, eventual indenização constituiria mais uma barreira, dentre tantas que infelizmente já existem, impedindo uma possível renovação dos laços familiares."
\end{abstract}

Contrariamente ao exaltado pelo voto prolatado leciona Rolf Madaleno:

"Há vozes que se posicionam em contrário à reparação do afeto que foi negado aos filhos, temendo que o pai condenado à pena pecuniária por sua ausência jamais tornará a se aproximar daquele rebento, em nada contribuindo pedagogicamente o pagamento da indenização para restabelecer o amor.

A indenização pecuniária visa a reparar o agravo psíquico sofrido pelo filho que foi rejeitado pelo genitor durante o seu crescimento, tendo a paga monetária a função de compensar o mal causado, preenchendo o espaço e o vazio deixados com a aquisição de qualquer outro bem material que o dinheiro da indenização possa comprar". ${ }^{35}$

\title{
E prossegue o renomado doutrinador:
}

"Decisões judiciais buscando reparar com indenizações pecuniárias a dilaceração da alma de um filho em fase de formação de sua personalidade, cujos pais se abstêm de todo e qualquer contato e deixam os seus filhos em total abandono emocional, não condenam a reparar a falta de amor, ou o desamor, nem tampouco a preferência de um pai sobre um filho e seu descaso sobre o outro, mas penalizam a violação dos deveres morais contidos nos direitos fundados na formação da personalidade do filho rejeitado.

\footnotetext{
${ }^{35}$ MADALENO, Rolf. Op. Cit.
} 
Penalizam o dano à dignidade humana do filho em estágio de formação, mas não com a intenção de recuperar o afeto não desejado pelo ascendente, mas principalmente, por seu poder dissuasório a demonstrar que, doravante, este velho sentimento de impunidade tem seus dias contados e que possa no futuro desestabilizar quaisquer outras inclinações de irresponsável abandono, se dando conta pelos exemplos jurisprudenciais, que o afeto tem um preço muito caro na nova configuração familiar."

Como observado anteriormente, o acórdão em tela foi provido por maioria, sendo essencial a análise do voto vencido do Desembargador Revisor Nilo Lacerda, cujo teor descreve a mudança das relações familiares e como o modelo de família atual busca pela relação saudável entre todos os membros desta:

"A família atual é vista não mais como um ente hierarquizado, patrimonialista. A família de hoje é plural, solidária, igualitária. É uma família eudemonista, ou seja, que prima pela busca de uma vida feliz, seja em âmbito individual seja coletivo.

Assim, a família atual deve se preocupar com o livre desenvolvimento da personalidade de cada um dos seus membros. A família tornou-se um ente funcionalizado, onde todos têm o objetivo de promover o livre desenvolvimento dos demais membros.

Assim, a família não deve mais ser entendida como uma relação de poder, ou de dominação, mas como uma relação afetiva, o que significa dar a devida atenção às necessidades manifestas pelos filhos em termos, justamente, de afeto $\mathrm{e}$ proteção.

Nesse contexto, em que a família torna-se o centro de desenvolvimento da personalidade de cada um de seus membros, a conduta do apelado revela-se violadora dos direitos do apelante, uma vez que o art. 227 da Constituição inclui no rol dos direitos da criança e do adolescente a convivência familiar."

É esse também o argumento defendido por Maria Celina Bodin de

Moraes:

"Desde a Constituição de 1988, houve um enorme salto qualitativo, digno de incluir o direito de família brasileiro entre os mais avançados do mundo. A vida familiar passou a girar em torno dos filhos, considerados juridicamente como pessoas às quais é devida "prioridade absoluta". Em conseqüência, deu-se a sua igualdade, com a proibição completa de discriminações e o seu reconhecimento independentemente da relação jurídica existente entre seus pais; a imprescritibilidade da ação de investigação de paternidade; a averiguação oficiosa da paternidade etc. Normas constitucionais e infraconstitucionais determinam, de modo indiscutível, a mais ampla proteção aos filhos, a ser observada pela família, em primeiro lugar, e também pela sociedade e pelo Estado." ${ }^{36}$

Prosseguindo com a sua tese, a grande civilista assim afirma:

\footnotetext{
${ }^{36}$ MORAES, Maria Celina Bodin de. "Deveres Parentais e Responsabilidade Civil"

IN Revista Brasileira de Direito das Famílias e Sucessões. Ano VII, No 31. Ago-Set 2005
} 
"O poder familiar é hoje concebido como um poder-dever posto no interesse exclusivo do filho e com a finalidade de satisfazer as suas necessidades existenciais, consideradas mais importantes, conforme prevê a cláusula geral de tutela da dignidade humana. Este também é, não por acaso, o teor do art. 227 da Constituição, ao determinar ser dever da família assegurar, com absoluta prioridade, às crianças e aos adolescentes os direitos à vida, saúde, alimentação, educação, lazer, profissionalização, cultura, dignidade, respeito, liberdade e convivência familiar e comunitária. O princípio, conhecido como "a doutrina jurídica da proteção integral", ramifica-se hoje em numerosos dispositivos legais, constantes das mais diversas leis e regulamentos, todos eles atribuindo às crianças e aos adolescentes preeminência na família, na sociedade e no Estado.”

Ao contrário da maioria dos desembargadores que votaram no presente caso, o Revisor entende que existe fundamento legal para considerar o abandono afetivo como ato ilícito e, consequentemente, embasar a indenização. Além do já citado art. 227 da Constituição Federal ainda utilizou-se do art. 1634 do Código Civil.

“A falta da relação paterno-filial dá ensejo à busca de compensação indenizatória em face dos danos que pais possam causar aos seus filhos, especialmente quando a eles é negada a convivência, o amparo afetivo, moral e psíquico, bem como a referência paterna ou materna concretas. Tal fato, sem dúvidas, acarreta a violação de direitos próprios da personalidade humana, maculando o princípio da dignidade da pessoa humana, que é um dos fundamentos da República, conforme se extrai do art. $1^{\circ}$, inciso III, da Constituição."

$(\ldots)$

"Logo, o fato de um pai deixar de prestar a assistência afetiva, moral e psicológica a um filho, violando seus deveres paternos, certamente deve ser considerado uma conduta ilícita, ensejadora de reparação no campo moral, violadora dos mandamentos Constitucional e Civil supra transcritos."

Não é por qualquer motivo que, já em 2005, Hironaka nos informava da necessidade de se priorizar a criança e seu saudável desenvolvimento e que os deveres parentais eram essenciais para esse fim. Caso a conduta dos pais não seguisse tal caminho, não haveria alternativa que não a sua responsabilização.

"Em conjugação com a responsabilidade há o viés naturalmente jurídico, mas essencialmente justo, de buscar-se indenização compensatória em face de danos que os pais possam causar a seus filhos, por força de uma conduta imprópria, especialmente quando a eles são negados a convivência, o amparo afetivo, moral e psíquico, bem como a referência paterna ou materna concretas, o que acarretaria a violação de direitos próprios da personalidade humana, de forma a magoar seus 
mais sublimes valores e garantias, como a honra, o nome, a dignidade, a moral, a reputação social; isso, por si só, é profundamente grave." ${ }^{37}$

Por fim, cabe informar que o Desembargador ressaltou em seu voto que existem Projetos tramitando no Congresso Nacional a respeito do tema, o que será objeto de análise mais aprofundada no próximo capítulo do presente trabalho.

Verificaremos a seguir dois julgados do Tribunal de Justiça do Rio de Janeiro, sendo cada qual com um posicionamento. Começaremos pelo caso no qual o Tribunal decidiu, por unanimidade, pela improcedência do pleito autoral.

$\begin{array}{lccccc}\text { "Ementa: AGRAVO INOMINADO NA } & \text { APELAÇÃO. AÇÃO } \\ \text { INDENIZATÓRIA. DIREITO } & \text { DE FAMÍLIA. ABANDONO AFETIVO E } \\ \text { MATERIAL. REQUISITOS } & \text { PARA } & \text { RESPONSABILIDADE } & \text { CIVIL. } \\ \text { INEXISTÊNCIA. } & & & \end{array}$

1. A causa de pedir se baseia no alegado abandono moral e material na seara do Direito de Família, envolvendo mãe e filha.

2. Como é cediço, a responsabilidade civil assenta-se no ato ilícito, dano e nexo causal, de modo que, não demonstrado algum deles, inviável se torna acolher qualquer pretensão indenizatória.

3. In casu, o pedido de indenização está calcado na responsabilidade subjetiva, tornando-se necessária a comprovação de todos os requisitos insculpidos no artigo 186 do Código Civil.

4. A lei estabelece obrigações dos pais aos filhos, como prestar-lhes alimentos ou exercitar sua guarda sob pena de perda do poder familiar, que não se enquadram, em regra, nas obrigações civis de cunho indenizatório por prática de ato ilícito.

5. A realidade que se extrai dos autos não demonstra que a demandada tenha falhado com os atributos inerentes ao poder familiar. Ao revés, revela que a própria autora optou por seguir um caminho censurável para sua vida, expondo-se às consequências dos seus atos.

6. Outrossim, a produção probatória não demonstra a efetividade da lesão sofrida e alegada, nos termos em que a autora busca demonstrá-la na inicial.

7. Por derradeiro, o insatisfatório desfecho da relação familiar não dá ensejo à responsabilização civil indenizável. Precedentes.

8. Recurso não provido." 38

\footnotetext{
${ }^{37}$ HIRONAKA, Giselda Maria Fernandes Novaes. Aspectos jurídicos da relação paterno-filial. Carta Forense, São Paulo, ano III, n. 22, p. 3, mar. 2005.

${ }_{38}$ TJ-RJ, Apelação Cível No 0005674-11.2006.8.19.0206, Des. Rel. Jose Carlos Paes, Rio de Janeiro, 21 mar. 2012.
} 
Interessante notar que, ao contrário do que ocorre na esmagadora maioria dos casos, essa demanda não foi proposta contra o pai e sim contra a mãe da autora que se disse abandonada.

Na exordial, a autora narrou que foi abandonada pela ré, sua mãe, durante a infância e adolescência, além de ter sofrido surras, maus-tratos e abuso sexual. Apesar dos fatos narrados, o juízo a quo julgou improcedente o pedido de indenização por danos morais.

Explica o Relator José Carlos Paes que o pedido autoral está calcado na responsabilidade subjetiva, sendo necessária a comprovação dos requisitos insculpidos no artigo 186 do Código Civil, sendo estes a culpa do agente, o dano e o nexo de causalidade. O que, para o relator, não restaram comprovados.

Ressaltou o Desembargador que no caso em tela não haveria nenhuma prova de descumprimento dos deveres legais da genitora com sua filha, tendo matriculado a mesma na escola e vacinado a criança sempre que necessário. Em suas palavras:

"Verifica-se que as partes em algumas ocasiões voltaram a conviver em moradia comum, e a ré em determinando período passou a cuidar da filha da autora, enquanto esta se dedicava ao entretenimento e uso de substâncias ilícitas.

Decerto que a conduta da recorrente em delegar a guarda de sua filha à ré retira qualquer credibilidade das acusações descritas na peça inicial. $\mathrm{E}$ isso, porque como bem destacou o Julgador a quo, a criança ou adolescente que sofre agressões e abusos da mãe nunca deixaria a própria filha aos cuidados da mesma.

Os documentos de fls. 52-55 noticiam que a apelante, na infância, recebeu as vacinas disponibilizadas na rede pública e estava matriculada em estabelecimento de ensino, demonstrando, desta forma, que a ré zelava pela educação e saúde da dela.

Assim, a realidade que se extrai dos autos não demonstra que a apelada tenha falhado com os atributos inerentes ao poder familiar. Ao revés, revela que a própria demandante optou por seguir um caminho tortuoso para sua vida, expondo-se às consequências dos seus atos."

Por fim, citou a decisão do Egrégio Superior Tribunal de Justiça de 2005, para embasar seu posicionamento. 
Apesar de algumas incongruências nos relatos da filha que buscava reparação apontarem para algumas inverdades e pela dificuldade de se averiguar, no caso em tela, se realmente ocorreu um abandono afetivo, fica nítido até pela leitura da ementa, que o Tribunal entendeu não era possível se indenizar o abandono moral. Isso fica evidente nos seguintes trechos:

\footnotetext{
"A lei estabelece obrigações dos pais aos filhos, como prestar-lhes alimentos ou exercitar sua guarda sob pena de perda do poder familiar, que não se enquadram, em regra, nas obrigações civis de cunho indenizatório por prática de ato ilícito.”

"Por derradeiro, o insatisfatório desfecho da relação familiar não dá ensejo à responsabilização civil indenizável. Precedentes.”
}

Esse posicionamento fica ainda mais evidenciado pelo fato de a decisão também se fundamentar no precedente criado pelo STJ, negando essa possibilidade de indenização.

Mais uma vez vemos aqui, o peso da decisão do Tribunal Superior e como ela reflete e influencia as decisões prolatadas nos Tribunais de Justiça.

Importante salientar que, embora o julgado tenha afirmado que o simples fato de a mãe ter dado todas as vacinas necessárias e ter matriculado a filha em uma escola, quando essa era uma criança, já seria suficiente para afastar a possibilidade de abandono afetivo, isso não é um entendimento unânime.

Ana Carolina Brochado Teixeira, por exemplo, entende que o dever dos pais nos cuidados com os filhos é muito mais amplo do que isso. Nos seus dizeres:

\footnotetext{
"A criação está diretamente ligada ao suprimento das necessidades biopsíquicas do menor, o que a atrela à assistência, ou seja, à satisfação das necessidades básicas, tais como cuidados na enfermidade, orientação moral, o apoio psicológico, as manifestações de afeto, o vestir, o abrigar, o alimentar, o acompanhar física e espiritualmente. Na verdade, assistência, criação e educação estão diretamente atreladas à formação da personalidade do menor, bem como ao escopo de realizar os direitos fundamentais dos filhos, seja em que seara for. O direito à educação, além desse aspecto geral, também se reporta ao incentivo intelectual, para que a criança e o adolescente tenham condições de alcançar sua autonomia, pessoal e profissional."
} 
Em sentido oposto ao caso anterior, destacamos outra decisão do mesmo tribunal, cuja ementa se transcreve:

"Ementa: RESPONSABILIDADE CIVIL. RELAÇÕES FAMILIARES. PRETENSÃO COMPENSATÓRIA DE DANOS MORAIS, AJUIZADA PELO FILHO EM FACE DO PAI, POR ABANDONO AFETIVO. SENTENÇA DE IMPROCEDÊNCIA DO PEDIDO. APELO DO AUTOR. ABANDONO PSICOLÓGICO E AFETIVO CARACTERIZADOS, PRINCIPALMENTE DIANTE DAS CARTAS ENVIADAS AO FILHO, DENEGRINDO A IMAGEM DE SUA GENITORA. PRECEDENTES DO TJRS E TJSP. INVERSÃO DOS ÔNUS SUCUMBENCIAIS. RECURSO CONHECIDO E PROVIDO." (0068032-79.2005.8.19.0001 (2007.001.45918) - APELACAO; TJRJ; DES. WERSON REGO - Julgamento: 22/11/2007 - DECIMA SEGUNDA CAMARA CIVEL) ${ }^{39}$

Do voto do Desembargador Werson Rego podemos extrair o entendimento de que existem situações em que o abandono moral dos pais em relação ao bem-estar - inclusive psicológico - dos filhos importam em violação, nítida, de atributos das personalidades destes, mormente à luz do princípio da dignidade da pessoa humana.

Apesar de existir jurisprudência do STJ em contrário, o Relator observou que tal posicionamento não mais se apresenta unânime, em virtude do fato de que no julgamento do REsp n ${ }^{\circ}$ 757411/MG foi prolatado o voto vencido do eminente Ministro Barros Monteiro, que se colocou favorável a reparação ao abandono moral.

Nas palavras do ilustre Desembargador:

\begin{abstract}
"Se um pai não pode ser culpado pelo fato de não amar ao filho - o que, por si, já não seria natural -, de outro lado, pode ser por negligenciá-lo - e, a nosso sentir, insisto, tanto nos aspectos materiais, quanto nos aspectos morais. Creio, sinceramente, que um pai que não exerce adequadamente seu poder familiar, que descura de seu dever de criar e de educar seus filhos, do de tê-los em sua companhia e guarda, do de assisti-los, quando tenha condições para fazê-lo, deve, sim, ser responsabilizado por negar aos mesmos uma formação plena como pessoas."
\end{abstract}

Cita ainda os doutrinadores Sérgio Cavalieri Filho para demonstrar que a Constituição deu maior dimensão ao dano moral quando estabeleceu o princípio da dignidade da pessoa humana.

\footnotetext{
39 TJ-RJ, Apelação Cível 0068032-79.2005.8.19.0001 (2007.001.45918), Des. Rel. Werson Rego, Rio de Janeiro, 22 nov. 2007.
} 
Fundamentou seu entendimento com os artigos 1634 e 1638 do Código Civil e com os artigos 22 e 249 do Estatuto da Criança e do Adolescente, demonstrando que o cuidado é dever dos pais e direito da prole.

A posição firmada pelo Desembargador no julgado traz a tona dois princípios fundamentais do Direito de Família, o do melhor interesse da criança e da paternidade responsável, ambos já analisados de forma mais aprofundada no primeiro capítulo. São eles, juntamente com outros princípios, como da dignidade da pessoa humana e da solidariedade familiar, que dão toda a base de sustentação da indenização por abandono afetivo, pois é a observância ou não desses princípios que vai estabelecer se a reparação é cabível no caso concreto.

Vemos, portanto, no excelente e muito bem fundamentado voto do Relator, que existem determinados direitos dos filhos que também são deveres parentais, impostos legal e constitucionalmente. Ao se negar esses direitos aos filhos, os pais, além de estarem desrespeitando imposições legais, estão deixando de prover necessidades básicas para um sadio desenvolvimento daqueles indivíduos como pessoas.

Cabe ressaltar também, uma ação apreciada pelo Tribunal de Justiça de Santa Catarina por sua peculiaridade na abordagem do tema de abandono afetivo. No caso em voga a referida peculiaridade está no polo ativo da demanda e na ação propriamente dita. Embora no caso se discuta a questão do abandono afetivo, não se trata de ação indenizatória proposta pelo filho abandonado e sim, uma ação de danos morais proposta pela mãe da criança, em nome próprio. Isso porque, o abandono afetivo sofrido pela criança teria também abalado moralmente a mãe. Vejamos a ementa:

"Ementa: DIREITO CIVIL - OBRIGAÇÕES - RESPONSABILIDADE CIVIL INDENIZAÇÃO POR DANOS MORAIS E MATERIAIS - PROCEDÊNCIA DAQUELA E IMPROCEDÊNCIA DESTA EM $1^{\circ}$ GRAU INCONFORMISMO DE RÉU E AUTORA - INSURGÊNCIA DO REQUERIDO - ILEGITIMIDADE PASSIVA AD CAUSAM POR OFENSAS PROFERIDAS EM PROCESSO - ACOLHIMENTO - PROCRASTINAÇÃO 
DO FEITO -RESPONSABILIDADE DO SISTEMA LEGAL-JUDICIÁRIOAUSÊNCIA DE DANOS MORAIS - INEXISTÊNCIA DE ILÍCITO INCONFORMISMO DA REQUERENTE - VALOR ÍNFIMO- ABANDONO MORAL DO FILHO PELO PAI -MAJORAÇÃO DO QUANTUM POR DANOS MORAIS - QUANTIA ADEQUADA- DANOS MATERIAIS - NEXO CAUSAL ENTRE ILÍCITO E DECRÉSCIMO FINANCEIRO DA AUTORA AUSÊNCIA - RECURSOS CONHECIDOS - PROVIMENTO PARCIAL AO DO RÉU E IMPROVIMENTO AO DA AUTORA

Incumbe ao advogado, e não à parte que lhe outorgou mandato, responder por supostos danos morais acarretados à parte contrária por eventuais excessos de linguagem. Não pode ser atribuível à parte, mas sim ao sistema legal-judiciário, o longo processamento do feito. $\mathrm{O}$ pai que se omite em cuidar do filho, abandonando-o, ofende a integridade psicossomática deste, acarretando ilícito ensejador de reparação moral. O sofrimento do filho abandonado pelo pai gera à figura materna daquele danos morais, principalmente quando a conseqüência desse sofrer é decisiva na formação da personalidade como um todo unitário. Inocorrendo recurso visando a redução do montante indenizatório fixado em $1^{\circ}$ grau, impõe-se a sua manutenção, mormente quando o quantum está subordinado aos danos morais sofridos pela requerente.Incomprovado que o decréscimo financeiro da autora não decorreu do término do auxílio financeiro do requerido, improcede a indenização por danos materiais." ${ }^{40}$

Alegou a autora que sofreu abalo psicológico em virtude de ter acompanhado o sofrimento do filho pelo abandono do pai, desenvolvendo um quadro depressivo e um tumor nos órgãos reprodutivos que precisaram ser extraídos por meio de cirurgia.

Entendeu o Tribunal por maioria que seria cabível a indenização por danos morais sofridos pela mãe da criança que sofreu abandono afetivo do pai, visto que a mesma acompanhou o sofrimento da criança.

O Relator designado, Monteiro Rocha, expôs seu ponto de vista em relação ao abandono afetivo, entendendo que a Constituição Republicana garante proteção às crianças:

"A ordem constitucional elevou a criança e o adolescente à categoria de sujeitos de direito e, incorporando a doutrina da proteção integral, assegurou-lhes uma série de garantias, visando proporcionar-lhes um crescimento sadio e harmonioso, condizente com a sua condição de pessoas em processo de desenvolvimento."

Nesse sentido, em seu artigo 227 assegurou o direito à convivência familiar como prioridade absoluta da criança e do adolescente. Da mesma

\footnotetext{
${ }^{40}$ TJ-SC, Apelação Cível No 2006.015053-0, Des. Rel. Monteiro Rocha, 08 mar. 2007.
} 
forma, o ECA regulamentou o referido dispositivo e nos artigos 25 e 19 garantiu o direito de serem educados e criados no seio familiar.

Aduz, ainda, existirem novas concepções de família "formada a partir de princípios éticos como o da solidariedade familiar e o da afetividade". Ressalta ainda que:

"No âmbito da relação parental, sendo os pais os orientadores da entidade familiar, há que se reconhecer a importância da existência tanto da figura materna como da paterna para a formação do indivíduo, cabendo a ambos os pais o dever de oferecer aos filhos amparo e afeto, criando-os e educando-os com o carinho indispensável à formação da sua personalidade."

Nesse argumento, o julgador tem a companhia de Gama e Orleans ${ }^{41}$, que ressaltam a importância tanto do pai quanto da mãe para o desenvolvimento de um indivíduo. Para eles, ambos devem se fazer efetivamente presentes na vida do filho, de modo a assisti-lo e orienta-lo. Só assim se colocaria um fim na cultura da "paternidade irresponsável” e se iniciaria uma consciência de que ambos os genitores tem papel primordial nesse processo.

Prosseguindo no voto, declarou da mesma forma, a imprescindibilidade da presença paterna para a formação do indivíduo e os efeitos negativos da ausência do mesmo. Sendo, para o Desembargador, inegável que a conduta é atentatória ao princípio da dignidade humana. E acrescenta:

"Entre os princípios constitucionais aplicáveis ao caso vertente, nomeia-se os seguintes: a) princípio da dignidade da pessoa humana; b) princípio da igualdade e respeito à diferença; c) princípio da solidariedade familiar; d) princípio da proteção integral a crianças, adolescentes e idosos; e) princípio da afetividade."

Argumenta, assim, que existe sim ilícito na conduta do genitor que abandonou emocionalmente seu filho e, vai além, ao entender que a conduta seria capaz de gerar dano indenizável à mãe da criança.

\footnotetext{
${ }^{41}$ GAMA, Guilherme Calmon Nogueira da e ORLEANS, Helen Cristina Leite de Lima. "Responsabilidade Civil nas Relações Familiares". IN Revista Brasileira de Direito das Famílias e Sucessões, $\mathrm{N}^{\circ}$ 24, Out-Nov 2011.
} 
"Nesse diapasão, indispensável afirmar-se que a responsabilidade civil do requerido está patenteada não somente contra a pessoa do seu filho, mas também contra a requerente, por via reflexa, pelo que desnecessária é a perquirição sobre o elemento subjetivo da culpa, por ser esta presumida às escâncaras."

Como visto, no caso em tela, a mãe do menor não interpôs ação indenizatória em nome do filho pelos abalos morais por ele enfrentados, mas sim em nome próprio, pleiteando a reparação pelos abalos que ela, como genitora do menor, teve que suportar ao acompanhar o sofrimento do filho abandonado.

Entendendo a maioria, nos termos do voto do relator que:

"Não se pode negar que, mesmo que de forma reflexa, é intenso o sofrimento de uma mãe pelo abandono afetivo do filho, tendo a requerente acompanhado sozinha a angústia do menor que estava entrando na fase da adolescência, época em que a base familiar tem importante papel para a configuração dos traços de personalidade."

Observamos, porém, que a decisão não foi unânime. O Desembargador Mazoni Ferreira se posicionou contra a condenação de indenização por danos morais sofridos pela genitora. Em suas palavras:

"Dissenti da maioria, ainda, no que tange ao reconhecimento da ocorrência de dano moral à autora pelo abandono afetivo e material do seu filho por parte do réu, pois entendo, nesse ponto, que os sentimentos experimentados pela autora são condizentes com o tipo de relacionamento que ela mantinha com o requerido, e não configuram dano moral passível de indenização."

Nota-se, portanto, a peculiaridade do caso em questão que entende não só que seja possível a indenização por danos morais sofridos pela criança que fora abandonada por seu genitor, mas também a indenização à mãe cujo filho fora abandonado por seu companheiro, ampliando as possibilidades de reparação do ato abandônico.

No Tribunal de Justiça de São Paulo destacamos três julgados importantes. Começaremos a análise pela decisão do Tribunal que indeferiu o pleito autoral, em seguida estudaremos a decisão em sentido contrário para, por fim, observarmos a decisão que chegou ao STJ.

"Ementa: Indenização. Dano moral. Abandono afetivo do genitor. Ausência de ato ilícito. Ao relacionamento desprovido de vínculo afetivo entre pai e filho não 
se atribui dolo ou culpa aptos a ensejar reparação civil. Inexistência de ato ilícito no âmbito do direito obrigacional. Indenização indevida. Recurso provido." ${ }^{42}$

No presente caso foi interposto Recurso de Apelação pelo réu em face da sentença que havia julgado procedente o pedido de danos morais em decorrência de abandono afetivo.

O Tribunal de São Paulo entendeu, nessa ocasião, que não haveria dano indenizável e proveu o recurso para reformar a sentença a quo, indeferindo o pleito autoral. Ressaltando o i. relator, ainda, que a responsabilidade civil extracontratual depende da presença de três pressupostos: (i) conduta culposa ou dolosa; (ii) nexo de causalidade; (iii) dano.

Nas palavras do ilustre relator Maia da Cunha:

"É fato que a dissolução de relacionamentos geram ressentimentos e acabam por desencadear um embate emocional e, não raro, os filhos menores ficam envolvidos em clima hostil e desfavorável ao desenvolvimento emocional, ainda mais quando há, como houve, constituição de nova família. Entretanto, a ofensa à integridade psíquica determinada pelo réu, com ou sem a concorrência da mãe do autor, não configura ilicitude geradora de danos morais. Até se reconhece a possibilidade de dor psicológica do requerente, mas em sua origem não se aloca culpa ou dolo apto a representar ato ilícito e, assim, estanca o desdobramento para a responsabilidade civil extracontratual, afastando a obrigação de ressarcimento. Os deveres dos pais com os filhos são, basicamente, de duas ordens, material e afetiva, e o seu descumprimento traz por consequências jurídicas a execução de alimentos e seus consectários legais, e a perda do poder familiar em caso de abandono afetivo."

Observar-se na posição de Maia da Cunha um aspecto que deve ser salientado. Embora ele reconheça que os pais possuem um dever de ordem afetiva, o que provavelmente o faz tendo por base os já, exaustivamente citados, artigos da Constituição Federal, do Código Civil e do Estatuto da Criança e do Adolescente correspondentes à matéria, o mesmo entende que a penalidade para o descumprimento desse dever é a perda do poder familiar, pois tal situação não ensejaria um ato ilícito merecedor de reparação. Dessa forma, o Relator se posiciona da mesma forma que o STJ

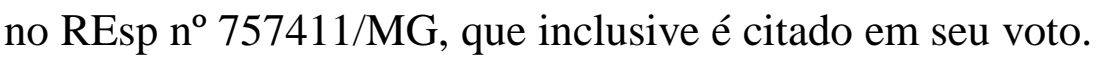

\footnotetext{
${ }^{42}$ TJ-SP, Apelação Cível No 5995064900, Des. Rel. Maia da Cunha, São Paulo, 11 dez. 2008.
} 
Entretanto, boa parte da doutrina e alguns magistrados, já se posicionaram de forma contrária a esse entendimento. Para eles, a utilização da sanção da perda do poder familiar nos casos de abandono afetivo, apenas premiaria o pai abandônico, já que este se veria livre de qualquer responsabilidade para com o seu filho. Esse é, por exemplo, o posicionamento de Gama e Orleans ${ }^{43}$, que entendem que a suspensão ou perda do poder familiar não serviriam para "coibir esse tipo de prática", além de não trazer nenhum "alento para o filho". Acrescentam, também, que não há que se preocupar com o fato de que essa indenização possa por fim a qualquer possibilidade de aproximação entre as partes, já que, quando um filho recorre ao Judiciário, é porque não existe mais nenhuma relação entre os envolvidos ou nunca existiu.

O segundo julgado do Estado de São Paulo é o que segue abaixo:

"Ementa: Responsabilidade civil. Dano moral. Autor abandonado pelo pai desde a gravidez da sua genitora e reconhecido como filho somente após propositura de ação judicial. Discriminação em face dos irmãos. Abandono moral e material caracterizados. Abalo psíquico. Indenização devida. Sentença reformada. Recurso provido para este fim." (Apelação Com Revisão 9170835-24.2007.8.26.0000; TJSP; $8^{\text {a }}$ Câmara de Direito Privado; Relator Caetano Lagrasta; 12/03/2008) ${ }^{44}$

A presente ação foi impetrada em face do genitor do autor que o abandonou e só reconheceu sua paternidade após ação judicial. A sentença prolatada em primeiro grau improveu o pedido.

Alega o recorrente que houve dano moral, uma vez que seu pai deu tratamento diferenciado aos demais filhos e netos, privando-o do direito à convivência, ao amparo afetivo, moral e psíquico, o que feriu sua dignidade, além do inegável abandono material a que se viu relegado.

O Desembargador Relator do caso Caetano Lagrasta votou pelo provimento do Recurso para reformar a decisão e condenar o réu ao

\footnotetext{
43 GAMA, Guilherme Calmon Nogueira da e ORLEANS, Helen Cristina Leite de Lima.Op. Cit. 44 TJ-SP, Apelação Cível No 9170835-24.2007.8.26.0000 (511.903-4/7-00), Des. Rel. Caetano Lagrasta, Rio de Janeiro, 12 mar. 2008.
} 
pagamento de indenização por danos morais decorrente do abandono afetivo do autor.

Destacou, em seu voto, que apesar de ninguém ser obrigado a amar, o abalo psíquico causado pelo abandono pode ser indenizado. Nas palavras do relator:

"Se o pai não alimenta, não dá amor, é previsível a deformação da prole. Isso pode acontecer, e acontece, com famílias regularmente constituídas.

Não se trata de aferir humilhações no decorrer do tempo. Ninguém é obrigado a amar o outro, ainda que seja o próprio filho. Nada obstante, a situação é previsível, porém, no caso da família constituída, ninguém, só por isso, requer a separação; ocorre que, na espécie, o abandono material e moral é atitude consciente, desejada, ainda que obstada pela defesa do patrimônio em relação aos outros filhos - o afastamento, o desamparo, com reflexos na constituição de abalo psíquico, é que merecem ser ressarcidos, diante do surgimento de nexo de causalidade."

Vale grifar a aprovação de Tartuce diante da forma como foi apreciado o caso:

"De início porque se concluiu pela existência de uma atuação dolosa do pai ao não reconhecer de forma espontânea o filho. O julgado considerou, para tal conclusão, parâmetros conceituais do dolo próprios da doutrina penal. Mais especificamente, o Acórdão fez uso da construção jurídica do dolo eventual, conceituado como "a intenção a ação delituosa, independente de obter ou não o resultado lesivo; ou melhor, o que o agente quer é a ação, assumindo o risco de qualquer resultado".

O Desembargador Relator constatou dolo eventual uma vez que o pai colocou o filho e seus descendentes em situação vexatória, ao não reconhecer o primeiro de forma espontânea. Além disso, de acordo com a decisão comentada, o dolo eventual também se fez presente uma vez que o pai assumiu a existência do relacionamento com a mãe do demandante, mas, mesmo assim, se recusou a submeter-se ao exame de DNA. Em suma, assumiu o pai os riscos de causar danos ao filho.

Apesar do conceito de dolo eventual ser tratado pelo Direito Civil como hipótese de um dolo puro, a ensejar a aplicação do princípio da reparação integral do dano, o caminho percorrido foi interessante, uma vez que são sempre salutares os diálogos interdisciplinares entre a própria ciência jurídica. Isso, reforce-se, mesmo com o enunciado pelo qual a responsabilidade civil independe da criminal. $"$ "5

Ainda comentando a decisão, também afirmou que no voto do Relator, ficou cristalina a violação dos deveres parentais por parte do

\footnotetext{
${ }^{45}$ TARTUCE. Flávio. Op. Cit.
} 
recorrido e que isso acarretou danos psicológicos ao recorrente, de modo a ficar caracterizada a existência do ato ilícito, do dano e do nexo de causalidade entre eles, existindo assim o dever de reparar.

Por fïm, vejamos a decisão do Tribunal de São Paulo que deu origem ao Recurso Especial julgado pelo STJ em 2012 a ser analisado posteriormente:

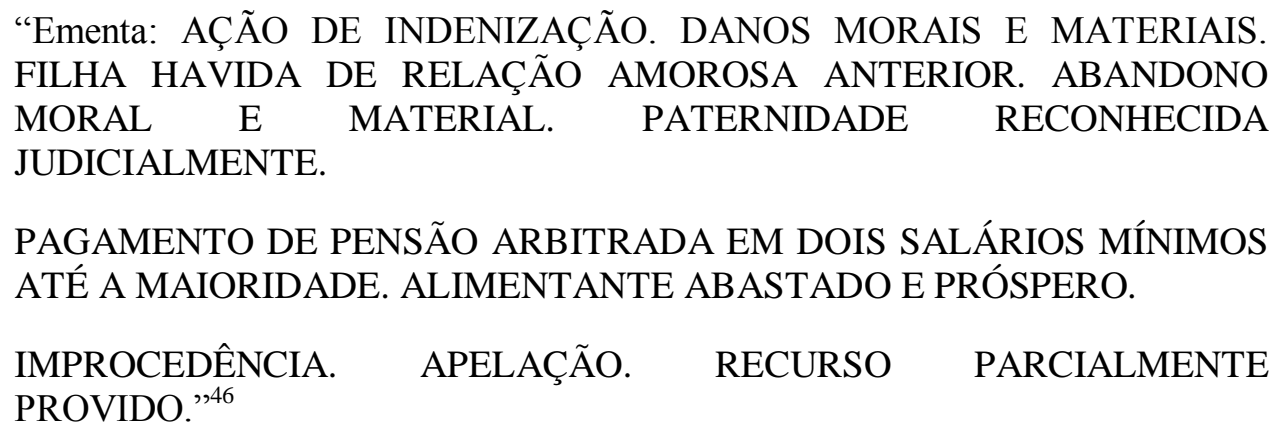

No presente caso o juízo a quo julgou improcedente o pleito autoral. Alega o réu que duvidava da paternidade e que fora impedido de ter relação mais afetuosa com a filha pela mãe da mesma. No entanto, entendeu a relatora que:

\begin{abstract}
"Não há como conceber a escusa do pai para o exercício efetivo da paternidade em relação à filha, a pretexto de que foi sempre impedido de fazê-lo em razão do alegado comportamento agressivo da mãe dela ou ainda a pretexto de que duvidava da paternidade até o reconhecimento judicial, acrescentando que pagou a pensão alimentícia mensal fixada judicialmente e depois elevada para dois (2) salários mínimos, até a maioridade.”

O Tribunal entendeu ser cabível a indenização por danos morais, reformando a sentença de primeira instância, nos termos do voto da
\end{abstract} relatora.

Fundamenta de forma muito perspicaz a Desembargadora seu entendimento no princípio constitucional da dignidade da pessoa humana, expresso no art. $1^{\circ}$, III da Carta Republicana e complementa:

"Ora, o ordenamento jurídico pátrio estabelece aos pais em relação aos filhos o dever de assistência, de criação e educação no seio da família, de companhia e guarda, de convivência, proibindo quaisquer designações discriminatórias

\footnotetext{
46 TJ-SP, Apelação Cível No 361.389-4/2-00, Des. Rel. Daise Fajardo Nogueira Jacot, São Paulo, 26 nov. 2008.
} 
relativas à filiação (v. artigos 229 da Constituição da República, 1.634 do Código Civil e 11 a 22 da Lei n 8.069/90).”

Após analisar a conduta do réu no caso concreto entendeu que: restou evidente "conduta culposa do réu pelo "abandono moral grave" e ao padecimento da autora, restando evidenciado o nexo causal entre aquela conduta ilícita e esse dano moral indenizável.”.

Ocorre que, o pai, inconformado com a decisão, interpôs um Recurso Especial, fazendo com que o STJ tivesse que enfrentar novamente essa temática. E é essa análise que será nosso próximo objeto de estudo. 


\section{Capítulo 4- A Nova Postura do Tribunal Superior: uma Mudança Paradigmática}

O Recurso Especial no 1159242/SP, chegou ao Superior Tribunal de Justiça cercado de expectativa. Isso porque, o tema até hoje ainda é muito controvertido, seja na doutrina ou na jurisprudência. Nessa última inclusive, mesmo com a maioria acompanhando o precedente criado pelo próprio Tribunal Superior, era crescente o número de decisões favoráveis ao abandono afetivo nos tribunais de justiça ao longo do país. Além disso, embora já existisse um posicionamento do Tribunal em 2005, a primeira decisão havia sido proferida pela Quarta Turma, enquanto o recurso em questão seria julgado pela Terceira Turma.

E toda a expectativa relatada se justificou. Com um posicionamento surpreendente, liderado pela relatoria da Ministra Nancy Andrighi, surgiu uma decisão paradigmática, que causou uma reviravolta e trouxe um novo foco para a questão.

Sem maiores desvios, passemos então para o tão importante julgado.

\footnotetext{
"Ementa: CIVIL E PROCESSUAL CIVIL. FAMÍLIA. ABANDONO AFETIVO. COMPENSAÇÃO POR DANO MORAL. POSSIBILIDADE.

1. Inexistem restrições legais à aplicação das regras concernentes à responsabilidade civil e o consequente dever de indenizar/compensar no Direito de Família.

2. O cuidado como valor jurídico objetivo está incorporado no ordenamento jurídico brasileiro não com essa expressão, mas com locuções e termos que manifestam suas diversas desinências, como se observa do art. 227 da CF/88.

3. Comprovar que a imposição legal de cuidar da prole foi descumprida implica em se reconhecer a ocorrência de ilicitude civil, sob a forma de omissão. Isso porque o non facere, que atinge um bem juridicamente tutelado, leia-se, o necessário dever de criação, educação e companhia - de cuidado - importa em vulneração da imposição legal, exsurgindo, daí, a possibilidade de se pleitear compensação por danos morais por abandono psicológico.

4. Apesar das inúmeras hipóteses que minimizam a possibilidade de pleno cuidado de um dos genitores em relação à sua prole, existe um núcleo mínimo de cuidados parentais que, para além do mero cumprimento da lei, garantam aos filhos, ao menos quanto à afetividade, condições para uma adequada formação psicológica e inserção social.
} 
5. A caracterização do abandono afetivo, a existência de excludentes ou, ainda, fatores atenuantes - por demandarem revolvimento de matéria fática - não podem ser objeto de reavaliação na estreita via do recurso especial.

6. A alteração do valor fixado a título de compensação por danos morais é possível, em recurso especial, nas hipóteses em que a quantia estipulada pelo Tribunal de origem revela-se irrisória ou exagerada.

7. Recurso especial parcialmente provido." ${ }^{, 47}$

Decidiu o Superior Tribunal de Justiça, nos termos do voto da relatora, por maioria, em dar provimento ao presente Recurso Especial, para condenar o réu ao pagamento de indenização por danos morais decorrente de abandono afetivo, contudo, reduziu o valor arbitrado pelo Tribunal de São Paulo.

Alegou o recorrente que não abandonou a filha e ainda que assim tivesse procedido, esse fato não se reveste de ilicitude, sendo a única punição legal prevista para o descumprimento das obrigações relativas ao poder familiar seria a perda do respectivo poder familiar, conforme o art. 1638 do Código Civil de 2002.

Aduz, ainda, que o posicionamento adotado pelo TJ/SP diverge do entendimento do STJ para a matéria, consolidado pelo julgamento do REsp n ${ }^{\circ} 757411 / \mathrm{MG}$, que afasta a possibilidade de compensação por abandono moral ou afetivo, conforme vimos em capítulo anterior no presente trabalho.

O brilhante voto da Ministra Nancy Andrighi se inicia com a fundamentação feita por ela da possibilidade de condenação por danos morais nas relações familiares. Entende que não existem restrições legais à aplicação das regras referentes à responsabilidade civil ao Direito de Família. Segundo ela, o art. 5o, V e X da CRFB e os artigos 186 e 927 do Código Civil tratam o tema de maneira ampla, sendo possível sua aplicação às relações familiares.

Sobre a alegação do recorrente de que a sanção prevista para seu comportamento seria unicamente a perda do poder familiar, a Ministra

\footnotetext{
${ }^{47}$ STJ, Recurso Especial No 1.159.242-SP, Min. Rel. Nancy Andrighi, Brasília, 24 abr. 2012
} 
ressaltou que essa é sim uma punição, mas não significa que seja única possível de ser aplicada, ou seja:

"Nota-se, contudo, que a perda do pátrio poder não suprime, nem afasta, a possibilidade de indenizações ou compensações, porque tem como objetivo primário resguardar a integridade do menor, ofertando-lhe, por outros meios, a criação e educação negada pelos genitores, e nunca compensar os prejuízos advindos do malcuidado recebido pelos filhos."

Moraes $^{48}$ concorda e afirma que os pais não são obrigados a amar seus filhos, mas devem orienta-los, sustenta-los e educa-los, como se amassem, pois esse é um dever imposto legalmente e não uma faculdade. Do contrário, existe sim a possibilidade de perda do familiar, mas sem que essa exclua em nenhum momento a possibilidade de reparação dos danos causados por essa negligência.

Argumenta, ainda a Ministra Nancy, que a relação entre pais e filhos possui um "liame objetivo e subjacente, calcado no vínculo biológico ou mesmo autoimposto - casos de adoção", sendo essa relação fruto de ato volitivo, seja por terem concorrido no nascimento ou terem voluntariamente adotado a criança.

Seria indiscutível, portanto, que esse vínculo não é apenas afetivo, mas também legal. De forma que, pacífico o entendimento doutrinário de que existem deveres decorrentes do poder familiar, como o de cuidado, convívio, criação e educação.

Sobre as tão discutidas e controversas ilicitudes da conduta e culpa do agente, destaca que:

"Sob esse aspecto, calha lançar luz sobre a crescente percepção do cuidado como valor jurídico apreciável e sua repercussão no âmbito da responsabilidade civil, pois, constituindo-se o cuidado fator curial à formação da personalidade do infante, deve ele ser alçado a um patamar de relevância que mostre o impacto que tem na higidez psicológica do futuro adulto.

Nessa linha de pensamento, é possível se afirmar que tanto pela concepção, quanto pela adoção, os pais assumem obrigações jurídicas em relação à sua prole, que vão além daquelas chamadas necessarium vitae.

\footnotetext{
${ }^{48}$ MORAES, Maria Celina Bodin de. Op. Cit.
} 
A ideia subjacente é a de que o ser humano precisa, além do básico para a sua manutenção - alimento, abrigo e saúde -, também de outros elementos, normalmente imateriais, igualmente necessários para uma adequada formação educação, lazer, regras de conduta, etc."

Pereira $^{49}$ nos lembra, ao comentar o REsp 1.106.637, que a Ministra já havia assumido posição vanguardista e louvável, já naquela ocasião, identificando-o dentre as responsabilidades do ser humano como pessoa e como cidadão.

Sobre o dever de cuidado, ressalta a Relatora que o cuidado é um fator essencial à criação e formação de um adulto com integridade física e psicológica, capaz de ter um convívio saudável com a sociedade. Assim, teria sido inserido no nosso ordenamento jurídico pela Carta Magna em seu artigo 227. Explica:

\begin{abstract}
"Vê-se hoje nas normas constitucionais a máxima amplitude possível e, em paralelo, a cristalização do entendimento, no âmbito científico, do que já era empiricamente percebido: o cuidado é fundamental para a formação do menor e do adolescente; ganha o debate contornos mais técnicos, pois não se discute mais a mensuração do intangível - o amor - mas, sim, a verificação do cumprimento, descumprimento, ou parcial cumprimento, de uma obrigação legal: cuidar.
\end{abstract}

Negar ao cuidado o status de obrigação legal importa na vulneração da membrana constitucional de proteção ao menor e adolescente, cristalizada, na parte final do dispositivo citado: “(...) além de colocá-los a salvo de toda a forma de negligência (...)".

$\operatorname{Rossot}^{50}$ acrescenta a esse ponto o entendimento de que o artigo 227 não menciona literalmente $\mathrm{o}$ afeto, mas que basta uma interpretação sistemática da Constituição Federal para perceber que existe um acolhimento jurídico do mesmo.

Outrossim, destaca a Ministra que não está discutindo o amor e sim a imposição legal do dever de cuidado, que é dever jurídico, corolário da liberdade de gerar ou adotar filhos. Em suas palavras:

\footnotetext{
${ }^{49}$ PEREIRA. Tânia da Silva. O "Cuidado" chega ao STJ. IN Revista Brasileira de Direito de Família e Sucessões, № 19, DEZ-JAN 2011.

${ }^{50}$ ROSSOT. Rafael Bucco. "O Afeto nas Relações Familiares e a Faceta Substancial do Princípio da Convivência Familiar”. IN Revista Brasileira de Direito de Família e Sucessões, № 9, AbrilMaio 2009.
} 
"O amor diz respeito à motivação, questão que refoge os lindes legais, situandose, pela sua subjetividade e impossibilidade de precisa materialização, no universo meta-jurídico da filosofia, da psicologia ou da religião.

O cuidado, distintamente, é tisnado por elementos objetivos, distinguindo-se do amar pela possibilidade de verificação e comprovação de seu cumprimento, que exsurge da avaliação de ações concretas: presença; contatos, mesmo que não presenciais; ações voluntárias em favor da prole; comparações entre o tratamento dado aos demais filhos - quando existirem -, entre outras fórmulas possíveis que serão trazidas à apreciação do julgador, pelas partes.

Em suma, amar é faculdade, cuidar é dever."

Da mesma forma já advertia Teixeira em 2005, ao dizer que "amor não é imposto, mas responsabilidade sim". 51

Dessa maneira, a violação do dever de cuidado, pela omissão do agente, atinge o bem jurídico tutelado e faz surgir o ilícito civil, capaz de gerar o dever de indenizar. Cabe, assim, ao julgador ponderar as situações fáticas para averiguar se foram cumpridos os deveres mínimos de cuidados parentais para ser assegurada a adequada formação psicológica e inserção social.

Explica, ainda, a Relatora que averiguar o dano e nexo de causalidade seria simples, visto que bastaria um laudo formulado por especialista que demonstre a existência de patologia psicológica causada pelo abandono afetivo. Contudo, deve-se entender que mesmo que o filho que fora abandonado consiga manter uma vida estável com emprego e aparente condição social saudável este sempre levará consigo a dor da ausência do pai. No caso em tela, destacou:

"Esse sentimento íntimo que a recorrida levará, ad perpetuam, é perfeitamente apreensível e exsurge, inexoravelmente, das omissões do recorrente no exercício de seu dever de cuidado em relação à recorrida e também de suas ações, que privilegiaram parte de sua prole em detrimento dela, caracterizando o dano in re ipsa e traduzindo-se, assim, em causa eficiente à compensação.”

Mais nos valemos de Maria Celina Bodin de Moraes ${ }^{52}$ que, da mesma forma, entende que no caso do abandono afetivo, o dano é in re

\footnotetext{
${ }^{51}$ TEIXEIRA, Ana Carolina Brochado. Op. Cit.

${ }^{52}$ MORAES, Maria Celina Bodin de. Op. Cit.
} 
ipsa, não sendo, portanto, necessária a sua comprovação através de perícia ou laudo psicológico.

Porém, o tema do abandono afetivo é tão controvertido, que até os partidários da reparação divergem sobre determinados aspectos. Tartuce ${ }^{53}$, por exemplo, entende pela necessidade de comprovação do dano moral sofrido, através de perícia psicológica, "uma vez que não se indeniza o dano hipotético ou eventual".

Demonstrada sua fundamentação, entendeu a relatora que é possível a indenização pecuniária a título de danos morais decorrente do abandono afetivo sofrido pela autora.

Contudo, conforme mencionado anteriormente, a decisão do Egrégio Tribunal não foi unânime, sendo o voto do Ministro Massami Uyeda vencido.

Entende o Ministro Uyeda que as consequências da interferência do Tribunal nas relações familiares, quando em discussão o afeto, podem ser desastrosas. Em suas palavras:

"Ora, se atentarmos para a realidade dos fatos, qualquer filho, qualquer filha, enfim, qualquer pessoa poderá dizer assim: mas estou sendo preterido em relação aos meus irmãos e qualquer dado subjetivo poderia motivar um pedido de indenização por dano moral. Ora, isso faria com que quantificássemos ou potencializássemos as mágoas íntimas - muitas legítimas, algumas supostamente legítimas - de filhos, de irmãos, de pais, de marido e mulher também, porque o dever dos cônjuges está entre prestar assistência, amar e tal. E os estudos indicam que esse amor é uma coisa da convivência."

(...)

"O voto de V. Exa. é pioneiro, Sra. Ministra Nancy Andrighi, mas também atento para a seguinte circunstância: se abrirmos essa porta como Tribunal de unificação jurisprudencial de interpretação da lei federal - e, aqui, no caso, é o Código Civil -, e V. Exa. também cita a Constituição, na qual um dos pilares do fundamento do Estado é a preservação da dignidade da pessoa humana, também não podemos esquecer que a interpretação dos princípios constitucionais requer razoabilidade, proporcionalidade. E, se for assim, não haverá mais tranquilidade.

Vamos causar aquilo que o Sr. Ministro Sidnei Beneti sempre fala: estabelecer uma cizânia dentro da família, porque essa pessoa, certamente, se o pai é

\footnotetext{
${ }^{53}$ TARTUCE. Flávio. Op. Cit.
} 
abastado, irá concorrer na herança no dia em que ele faltar, ou esse pai negligente, vamos dizer."

Posicionou-se, ainda o Ministro Sidnei Beneti, que, segundo ele, sua opinião se enquadraria entre os votos da Ministra Nancy e do Ministro Uyeda. Entende o Ministro que é possível a existência de dano moral e a consequente indenização no âmbito familiar. Nas suas palavras:

"Nesse sentido a interpretação dos dispositivos legais anotados pelo voto da E. Relatora (CF, arts. $1^{\circ}$, III, $5^{\circ}$, V e X, e CC/2001,arts. 186 e 927, e ECA, art. 227), não podendo ser erigida como eximente indenizatória a sanção constituída pela perda do poder familiar (CC/2002, art. 1638, II, c.c. art. 1634, II), porque de uma sanção, de natureza familiar, por ação ou omissão reprováveis do genitor, a perda do poder familiar, não será congruente extrair o despojamento de direito a outra sanção, de consequências patrimoniais, consistente na indenização por dano moral, até porque o contrário significaria impor ao lesado a perda de direito (indenização por dano moral) devido a haver sido vítima de ação ou omissão do mesmo ofensor (abandono), ao mesmo tempo em que isso ensejaria dupla vantagem ao ofensor, com o despojamento de responsabilidades familiares e indenizabilidade de dano moral (tornando-se verdadeiro incentivo ao abandono familiar)."

Entende que, em relação ao arbitramento dos valores da indenização,

os valores devem ser proporcionais à ação ou omissão do agente em sua provocação:

"Ponderados todos esses elementos, e realçando-se que a fixação de valores a título de indenização moral não é jamais matemática, mas estimativa, à luz de condições interagentes entre si em cada caso concreto, o que impede que se comparem objetivamente, valores com o de outros casos concretos, deve-se dosar o valor dos danos morais, proporcionalmente à responsabilidade do genitor"

Votou, também, o Ministro Paulo de Tarso Sanseverino, entendendo que o caso em tela se caracteriza como uma excepcionalidade, merecendo ser reconhecida a ocorrência do ato ilícito causador do dano moral. Ressaltou que a responsabilidade civil no âmbito familiar não pode ser equiparada à responsabilidade civil extracontratual:

“Assim, pela própria natureza delicada dos relacionamentos familiares, a responsabilidade civil no Direito de Família não pode ser equiparada à responsabilidade civil extracontratual em geral, sob pena de se exigir, no trato familiar diário, uma cautela incompatível com as relações que se firmam no âmbito da família, além de se conduzir a uma indesejável patrimonialização das relações pessoais, justamente em seu viés mais íntimo. 
Não se pode olvidar que as frustrações experimentadas no seio familiar, além de contribuírem para o crescimento e para o desenvolvimento do indivíduo, são, em parte, próprias da vida e, por isso mesmo, inevitáveis.

Sendo assim, entendo que o reconhecimento de dano moral em matéria de família é situação excepcionalíssima, devendo-se admitir apenas em casos extremos de efetivo excesso nas relações familiares.”

Argumentou, ainda, que apenas o abandono completo e notório do filho pelo pai seria capaz de gerar a responsabilidade civil do genitor, sob pena de justificar-se o eventual abuso por parte dos filhos que restarem insatisfeitos com sua criação.

"Felizmente, dispõe-se de uma larga margem de liberdade para educar e criar os filhos do modo que melhor se aprouver, sendo que desvios, percalços e falhas são inerentes ao processo de educação e de criação.

O dever de cuidado, pois, apresenta um conteúdo inegavelmente subjetivo.

Assim, imprescindível apoiar-se sobre firme substrato e esclarecer que o abandono afetivo apenas ocorre quando o progenitor descumpre totalmente seu dever de cuidado, infringindo flagrantemente as mais comezinhas obrigações para com seu filho.

Evita-se, desse modo, eventual abuso por parte de filhos que, insatisfeitos com episódios específicos de sua criação, pleiteiam a indenização por danos supostamente sofridos."

Dessa forma, acompanhou o voto da Ministra relatora, observando a devida redução do montante apurado pelo Tribunal a quo a título de indenização por danos morais.

Observamos então, com a prolação da referida decisão, uma guinada no entendimento do Superior Tribunal de Justiça, que não só assumiu a possibilidade de se indenizar por abandono afetivo, como também alçou o dever de cuidado a um patamar que, anteriormente, só era observado pelas normas jurídicas reiteradamente citadas.

Com o posicionamento em tela, o Tribunal não apenas criou uma nova jurisprudência, mas também, sinalizou com a adoção de uma interpretação mais principiológica, mais atenta à dignidade da pessoa humana e aos demais princípios basilares da Constituição Federal da República Federativa do Brasil. E essa concretização dos princípios 
constitucionais, é fundamental para sustentação de um Direito de Família mais consoante com a nova realidade social. Afinal de contas, para a construção de uma sociedade justa é necessário que se protejam os indivíduos que compõem o núcleo familiar, centro primordial de toda e qualquer sociedade.

É de grande revelo destacar o comentário de Rodrigo Pereira da Cunha com relação ao julgado.

\begin{abstract}
"Em 24.04.2012, a 4 a turma do Superior Tribunal de Justiça trouxe outra posição da Corte Superior, sob a relatoria da Ministra Nancy Andrighi, em que demonstra entender e traduzir melhor os novos valores e paradigmas do Direito de Família contemporâneo. Certamente um filho que precisou recorrer à justiça para pedir ao Estado-Juiz uma reparação civil, já sabe que se antes já não tinha seu pai por perto, com a condenação ele se afastará ainda mais. Entretanto, quando se busca tal reparação, certamente já passou toda sua vida mendigando o amor deste pai. Nesta referida decisão, o STJ colocou em seu devido lugar o afeto como valor jurídico, no sentido em que ele se traduz como ações e omissões (...)" ${ }^{54}$
\end{abstract}

Ademais, cabe acrescentar, que apesar do posicionamento vanguardista encabeçado pela Ministra Nancy Andrighi, existe uma parte da doutrina que entende que existe uma exigência legal no ordenamento pátrio, de que os pais não apenas observem o dever de cuidado, mas também, um dever de afeto, de amor para com os filhos. Faz parte dessa corrente, por exemplo, $\operatorname{Rossot}^{55}$, que defende que a exigência de afeto está contida no ordenamento jurídico brasileiro, tendo em vista a internalização de dois tratados internacionais: a Declaração Universal dos Direitos da Criança (1959) e a Convenção Internacional do Direito das Crianças (1989). E já que em ambas existe a exigência expressa de que seja fornecido amor para garantir um sadio desenvolvimento da criança, não poderiam os pais se furtar de cumprir o mandamento legal, sob pena de ter que indenizá-los.

Por fim, cumpre informar, que o pai que foi condenado a reparar a filha em R\$ 200 mil reais por abandono afetivo, no REsp n ${ }^{\circ}$ 1159242/SP, apresentou embargos de divergência alegando que esta última decisão contraria a decisão proferida pela Quarta Turma em 2005. O caso será

\footnotetext{
${ }^{54}$ PEREIRA, Rodrigo da Cunha. Op. Cit.

${ }^{55}$ ROSSOT. Rafael Bucco. Op. Cit.
} 
relatado pelo Ministro Marco Buzzi. Vale lembrar, que nenhum dos Ministros que compõem, atualmente, a Quarta Turma do Tribunal, participaram do julgamento do caso de 2005. Agora nos resta apenas aguardar e conferir de que forma o Superior Tribunal de Justiça se manifestará quanto à questão.

Apesar de ser de suma importância demonstrar a divergência jurisprudencial e doutrinária acerca do abandono afetivo, não podemos deixar de abordar o fato de que a questão também está na pauta do Congresso Nacional. Atualmente, existem dois Projetos de Lei em trâmite, uma na Câmara dos Deputados e outro no Senado Federal, que versam justamente sobre o tema e podem traçar novos rumos para a questão. Diante de sua vital importância para a discussão posta, é que estes PLs serão os nossos objetos de estudo no último capítulo desse trabalho. 


\section{Capítulo 5- A Questão em Debate no Congresso Nacional}

Desde que o tema chegou aos tribunais no início dos anos 2000 e, principalmente, após o Superior Tribunal de Justiça ter julgado o primeiro caso, é crescente o debate acerca das obrigações parentais na criação dos filhos e das consequências provenientes do seu descumprimento dentro da sociedade brasileira. Dentro das Casas Legislativas federais isso não foi diferente. Tanto na Câmara dos Deputados quanto no Senado Federal existem Projetos de Lei que visam estabelecer algum tipo de regulamentação legal específica acerca do controverso tema do abandono afetivo.

Por uma questão meramente cronológica, começaremos pela análise do Projeto de Lei do Senado denominado de PLS 700 de 2007. Posteriormente, faremos a análise da proposta que tramita na Câmara dos Deputados sob o n 4.294 de 2008.

\section{1- As Proposições do Projeto de Lei no 700 de 2007 e sua Tramitação no Senado Federal}

O Projeto de autoria do Senador do Rio de Janeiro Marcelo Crivella visa à modificação do Estatuto da Criança e do Adolescente, de modo que passe a constar previsão normativa específica sobre a reparação pecuniária decorrente do abandono afetivo. O mesmo é composto por quatro artigos que passaremos a analisar agora.

Em seu primeiro artigo o Projeto estabelece que o artigo $4^{\circ}$ da lei 8.069 de 13 de julho de 1990 (ECA) seja renumerado, de modo que o seu parágrafo único se transforme em parágrafo $1^{\circ}$, e sejam acrescidos os parágrafos $2^{\circ}$ e $3^{\circ}$ com as seguintes redações: 
“\$ $\mathbf{2}^{\mathbf{0}}$. Compete aos pais, além de zelar pelos direitos de que trata o art. $3^{\circ}$ desta Lei, prestar aos filhos assistência moral, seja por convívio, seja por visitação periódica, que permitam o acompanhamento da formação psicológica, moral e social da pessoa em desenvolvimento.

$\S 3^{\mathbf{0}}$. Para efeitos desta Lei, compreende-se por assistência moral devida aos filhos menores de dezoito anos:

I - a orientação quanto às principais escolhas e oportunidades profissionais, educacionais e culturais;

II - a solidariedade e apoio nos momentos de intenso sofrimento ou dificuldade;

III - a presença física espontaneamente solicitada pela criança ou adolescente e possível de ser atendida. (NR)",56

Pela redação dos referidos parágrafos, nota-se a intenção de evidenciar de forma inequívoca a obrigação dos pais de prestarem toda a assistência necessária para o sadio desenvolvimento do filho. Para isso, o parágrafo $3^{\circ}$ (terceiro) elenca quais seriam as formas de assistência moral exigidas, além das já estabelecidas em outros dispositivos normativos.

Já o segundo artigo do Projeto modifica 7 (sete) artigos do ECA, a saber: $5^{\mathrm{o}}, 22,24,56,58,129$ e $130 .^{57}$

$\mathrm{O}$ artigo $5^{\circ}$ da Lei 8.069 passaria a conter um parágrafo único prevendo que:

"Parágrafo único. Considera-se conduta ilícita, sujeita a reparação de danos, sem prejuízo de outras sanções cabíveis, a ação ou a omissão que ofenda direito fundamental de criança ou adolescente previsto nesta Lei, incluindo os casos de abandono moral. (NR)",58

Verifica-se nessa inclusão um aspecto fundamental para por fim a um dos principais argumentos para a não concessão de indenização por abandono afetivo, a de que o ato abandônico não seria uma conduta ilícita e, portanto, não seria passível de reparação pecuniária.

\footnotetext{
${ }^{56}$ Artigo $1^{\circ}$ do Projeto de Lei ${ }^{\circ} 700$ de 2007 do Senado Federal, em tramitação. Disponível em: http://www.senado.gov.br/atividade/materia/detalhes.asp?p_cod_mate $=83516$

${ }^{57}$ Artigo $1^{\circ}$ do Projeto de Lei $n^{\circ} 700$ de 2007 do Senado Federal, em tramitação. Disponível em: http://www.senado.gov.br/atividade/materia/detalhes.asp?p_cod_mate $=83516$

${ }^{58}$ Artigo $2^{\circ}$ do Projeto de Lei $n^{\circ} 700$ de 2007 do Senado Federal, em tramitação. Disponível em: http://www.senado.gov.br/atividade/materia/detalhes.asp?p_cod_mate $=83516$
} 
Já o artigo 22 do ECA teria sua redação modificada para passar a conter os deveres de convivência e assistência material e moral, além daqueles já previstos em seu texto atual.

A proposta de alteração do artigo 24 do Estatuto da Criança e do Adolescente em nada inovou em relação ao texto atual, a não ser pela substituição da expressão "pátrio poder" por "poder familiar", o que, posteriormente, foi efetivado pela Lei $\mathrm{n}^{\circ} 12.010$ de 2009 , mas que fazia sentido à época da criação do Projeto de lei.

$\mathrm{O}$ artigo 56 do referido Estatuto, de acordo com o proposto no Projeto, passaria a ter um inciso IV (quatro) que determinaria que os dirigentes de estabelecimentos de ensino fundamental teriam o dever de comunicar ao Conselho Tutelar, os casos de "negligência, abuso ou abandono na forma prevista nos arts. $4^{\circ}$ e $5^{\circ}$ desta Lei.".

No que tange ao artigo 58, ainda do mesmo diploma, a nova redação incluiria a exigência de respeito, no processo educacional, dos valores morais e éticos.

O parágrafo único do artigo 129, por sua vez, de acordo com o PLS, passaria a incluir a necessidade de observância do artigo 22, também do ECA, nos casos de destituição de tutela, suspensão ou perda do poder familiar.

O artigo 130, último a ser modificado pelo segundo artigo do Projeto do Senador Marcelo Crivella, passaria a incluir a hipótese de negligência no rol de possibilidades de concessão de medida cautelar de afastamento do pai/mãe agressor da moradia comum do menor.

O terceiro, e mais polêmico artigo do PLS 700 de 2007, visa a inclusão do artigo 232-A ao Estatuto da Criança e do Adolescente, que versaria da seguinte forma: 
"Art. 232-A. Deixar, sem justa causa, de prestar assistência moral ao filho menor de dezoito anos, nos termos dos $\S \S 2^{\circ}$ e $3^{\circ}$ do art. $4^{\circ}$ desta Lei, prejudicando-lhe o desenvolvimento psicológico e social.

Pena - detenção, de um a seis meses."

Esse é, sem dúvidas, o ponto mais controverso do Projeto de Lei em análise. Com esse artigo verificamos a intenção do Projeto em definir o abandono afetivo não apenas como um ilícito civil, mas também penal.

Entretanto, como veremos em momento posterior, de acordo com os pareceres dados pelas Comissões competentes do Senado Federal, dificilmente, essa caracterização do abandono afetivo como ilícito penal será aprovada, ainda que o restante do Projeto o seja.

Por fim, o quarto e último artigo, determina que a Lei entraria em vigor na data de sua publicação.

Antes de passarmos para a tramitação do PLS e para os pareceres e relatórios das Comissões, é fundamental que se verifique a justificação dada ao Projeto.

O Senador Marcello Crivella traz importantes argumentos em sua justificação. Ele ressalta que a lei não tem o poder de modificar a consciência dos pais, "mas pode prevenir e solucionar os casos intoleráveis de negligência para com os filhos.". ${ }^{60}$

O Projeto, segundo o seu autor, teria seu fundamento no artigo 227 da Constituição Federal, que impõe ao Estado, a sociedade e a família o dever de assegurar a crianças e adolescentes, além de outros direitos, o direito à dignidade e ao respeito.

\footnotetext{
${ }^{59}$ Artigo $3^{\circ}$ do Projeto de Lei $n^{\circ} 700$ de 2007 do Senado Federal, em tramitação. Disponível em: http://www.senado.gov.br/atividade/materia/detalhes.asp?p_cod_mate $=83516$

${ }^{60}$ CRIVELLA, Marcelo. Justificação do Projeto de Lei $\mathrm{n}^{\mathrm{o}} 700$ de 2007 do Senado Federal, em tramitação. Disponível em: http://www.senado.gov.br/atividade/materia/detalhes.asp?p_cod_mate=83516
} 
Para o Congressista, não há como negar que o abandono moral traz graves consequências para a formação "psicológica e social dos filhos". 61

O objetivo principal do PLS 700/2007 não seria impor uma obrigação de amar, mas sim, esclarecer que os pais têm os seguintes deveres:

"acompanhar a formação dos filhos, orientá-los nos momentos mais importantes,
prestar-lhes solidariedade e apoio nas situações de sofrimento e, na medida do
possível, fazerem-se presentes quando o menor reclama espontaneamente a sua
companhia.". ${ }^{2}$

Ressalta a necessidade do Projeto também por conta da divergência jurisprudencial acerca da questão.

Alega ainda, que embora entenda que a Constituição Federal, o Código Civil e o Estatuto da Criança e do Adolescente já contemplam a necessidade dessa assistência especial, seria necessária a criação de uma regra que não deixasse qualquer dúvida de que o abandono afetivo seria um ilícito civil e que também deve ter repercussões na esfera penal.

Ademais, afirma que a relação entre pais e filhos jamais pode ser reduzida a uma questão econômica, como se bastasse apenas o pagamento de pensão alimentícia. A manutenção do dever de sustento em nada pode substituir as necessidades de atenção, orientação e presença.

Marcelo Crivella alegou que teve a preocupação de delimitar de forma bem objetiva a possibilidade de repercussão penal do abandono afetivo em seu Projeto de lei, exigindo para tal, a comprovação do dano psicológico e social para que ocorra a consumação.

Lembrou ainda dos compromissos internacionais firmados pelo Brasil que exigem um aperfeiçoamento das normas legais que protegem as

\footnotetext{
${ }^{61}$ CRIVELLA, Marcelo. Justificação do Projeto de Lei no 700 de 2007 do Senado Federal, em tramitação. Disponível em: http://www.senado.gov.br/atividade/materia/detalhes.asp?p_cod_mate $=83516$

${ }^{62}$ CRIVELLA, Marcelo. Justificação do Projeto de Lei ${ }^{\circ} 700$ de 2007 do Senado Federal, em tramitação. Disponível em: http://www.senado.gov.br/atividade/materia/detalhes.asp?p_cod_mate=83516
} 
crianças e adolescentes, a saber: Declaração dos Direitos das Crianças de 1959 e Convenção da ONU Sobre Direitos da Criança de 1989.

Finalizando sua justificação, o Senador ressaltou que acredita que a aprovação de seu Projeto de lei permitirá a indubitavel caracterização do abando afetivo como ilícito, além de pôr fim à insegurança causada por diversas decisões judiciais contradiótiras entre si. E que conta com esses dois fatores para que o Congresso aprove de maneira rápida a sua proposta.

Após a apresentação do Projeto e o prosseguimento da sua tramição, o mesmo foi enviado para a Comissão de Constituição, Justiça e Cidadania, sob a relatoria do Senador Valdir Raupp.

Embora antes de ser dado o parecer definitivo da Comissão o Senador Augusto Botelho tenha sido escolhido como o relator ad hoc, foi o relatório elaborado, anteriormente, por Valdir Raupp que foi adotado na íntegra como o referido parecer.

Antes de adentrarmos na análise do parecer da Comissão, cabe destacar que por conta de um requerimento do Senador Marco Maciel de número 1.187 de 2008, o PLS 700/07 passou a tramitar em conjunto com outros 13 Projetos. Todavia, por conta de outro requerimento de número 448 de 2009, de autoria do Senador Valdir Raupp, o mesmo voltou a tramitar sozinho.

Além disso, o próprio Senador Marcelo Crivella propôs uma emenda ao PLS para alterar o artigo 1.589 do Código Civil, de modo que a expressão "poderá visitá-los e tê-los em sua companhia" fosse susbstituída por "deverá visitá-los e tê-los em sua companhia". 63

Passemos então a destacar os principais pontos do posicionamento adotado no parecer.

\footnotetext{
${ }^{63}$ RAUPP, Valdir. Parecer da Comissão de Constituição, Justiça e Cidadania sobre o Projeto de Lei $n^{\circ} 700$ de 2007 do Senado Federal, em tramitação. Disponível em: http://www.senado.gov.br/atividade/materia/detalhes.asp?p_cod_mate=83516
} 
Logo de início foi afastada qualquer possibilidade de inconstitucionalidade formal ou material.

Posteriormente, foi grifada uma suposta inadequação do termo "abandono moral" utilizado no Projeto para designar a conduta abandônica, tendo em vista que, usualmente, esta seria usada pela doutrina e pela jurispudência para se referir ao crime previsto no artigo 247 do Código Penal. Diante desta crítica, foi sugerido no parecer a adoção do termo "abandono afetivo".

Outra crítica feita pela Comissão, ao Projeto de Lei, foi a de que a responsabilização penal por abandono afetivo seria excessiva, principalmente, pelo fato de a questão ser bastante delicada e controversa. Segundo o parecer, seria temeroso se estabelecer uma possibilidade de punição no âmbito penal diante de uma questão em que tanto pode existir um ato abandônico, quanto uma alienação parental, pelo fato de a criança ter absorvido sentimentos de ódio e vingança daquele que detém a sua guarda (situação bem comum em casos de separações conturbadas de casais). Diante desta dificuldade de se identificar o que seria abandono e o que seria alienação parental, seria muito extremado e perigoso se valer do direito penal, que tem "caráter de última ratio", para regular a questão, já que a indenização no âmbito civil seria suficiente para solucionar o caso.

Feitas essas ponderações, a Comissão de Constituição, Justiça e Cidadania votou de forma favorável à aprovação do Projeto de Lei do Senado de $\mathrm{n}^{\mathrm{o}} 700$ de 2007 com a Emenda $\mathrm{n}^{\mathrm{o}}$ 01-CCJ, proposta pelo próprio Senador Crivella, e outras 5 (cinco) Emendas propostas no relatório do Senador Raupp e adotadas pelo parecer em tela.

A Ementa de $n^{\circ} 02$ proposta na Comissão foi a mudança da ementa do PLS para: 
"Altera as Leis $\mathrm{n}^{\circ}$ 8.069, de 13 de julho de 1990 - Estatuto da Criança e do Adolescente, e $\mathrm{n}^{\mathrm{o}}$ 10.406, de 10 de janeiro de 2002 - Código Civil, para caracterizar o abandono afetivo como ilícito civil." ${ }^{64}$

$\mathrm{Na}$ Emenda de $\mathrm{n}^{\circ} 03$ a mudança proposta é a substituição da expressão "assistência moral" por "assistência afetiva", nos parágrafos $2^{\circ} \mathrm{e}$ $3^{\circ}$ do artigo $4^{\circ}$ do Estatuto da Criança e do Adolescente, nos termos propostos pelo PLS 700/2007. ${ }^{65}$

Da mesma forma, ocorre com a Emenda de $n^{\circ}$ 04, na qual se propõe a substituição da expressão "abandono moral" por "abandono afetivo", no parágrafo único do artigo $5^{\circ}$ do ECA, na forma proposta pelo artigo $2^{\circ}$ do Projeto de Lei. $^{66}$

A penúltima Emenda do parecer supracitado, por sua vez, requer a supressão do polêmico artigo $3^{\circ}$ do projeto do Senador Crivella, que acarretaria na responsabilização penal do abando afetivo, e a renumeração dos demais artigos. ${ }^{67}$

Por fim, a última Emenda proposta pela Comissão é a supressão da proposta de alteração do artigo 24 do Estatuto da Criança e do Adolescente contida no artigo $2^{\circ}$ da PLS 700 de 2007 e a manutenção de sua redação original. $^{68}$

Observamos, então, que o Projeto foi aprovado pela Comissão de Constituição, Justiça e Cidadania, embora tenham sido feitas algumas

\footnotetext{
${ }^{64}$ Ementa no $^{\circ} 02$ do parecer da Comissão de Constituição, Justiça e Cidadania do Senado sobre o Projeto de Lei $\mathrm{n}^{\circ} 700$ de 2007 do Senado Federal, em tramitação. Disponível em: http://www.senado.gov.br/atividade/materia/detalhes.asp?p_cod_mate=83516

${ }^{65}$ Ementa $\mathrm{n}^{\circ} 03$ do parecer da Comissão de Constituição, Justiça e Cidadania do Senado sobre o Projeto de Lei $\mathrm{n}^{\circ} 700$ de 2007 do Senado Federal, em tramitação. Disponível em: http://www.senado.gov.br/atividade/materia/detalhes.asp?p_cod_mate $=83516$

${ }^{66}$ Ementa n ${ }^{\circ} 04$ do parecer da Comissão de Constituição, Justiça e Cidadania do Senado sobre o Projeto de Lei $\mathrm{n}^{\circ} 700$ de 2007 do Senado Federal, em tramitação. Disponível em: http://www.senado.gov.br/atividade/materia/detalhes.asp?p_cod_mate $=83516$

${ }^{67}$ Ementa n $^{\circ} 05$ do parecer da Comissão de Constituição, Justiça e Cidadania do Senado sobre o Projeto de Lei $\mathrm{n}^{\circ} 700$ de 2007 do Senado Federal, em tramitação. Disponível em: http://www.senado.gov.br/atividade/materia/detalhes.asp?p_cod_mate $=83516$

${ }^{68}$ Ementa n$^{\circ} 06$ do parecer da Comissão de Constituição, Justiça e Cidadania do Senado sobre o Projeto de Lei $\mathrm{n}^{\mathrm{o}} 700$ de 2007 do Senado Federal, em tramitação. Disponível em: http://www.senado.gov.br/atividade/materia/detalhes.asp?p_cod_mate $=83516$
} 
propostas de Emendas importantes, sendo a principal delas, a que suprime a responsabilidade penal pelo abandono afetivo de um filho.

Conforme mencionado, anteriormente, o Projeto em questão também foi encaminhado para a Comissão de Direitos Humanos e Legislação Participativa, que será a responsável por dar a decisão terminativa com relação ao mesmo.

Porém, a referida Comissão ainda não deu um parecer, o que, segundo notícias do site do Senado Federal, deve ocorrer ainda no primeiro semestre de $2013 .^{69}$

Até o presente momento, o que existem são 3 (três) relatórios da mesma Comissão, cada um de um relator, sendo os dois primeiros de quase idêntico conteúdo e o terceiro um complemento destes, embora com voto parcialmente divergente.

O primeiro relatório elaborado data de 2010 e é de autoria do Senador Gerson Camata. Nele, o relator se coloca integralmente de acordo com todas as Emendas propostas pela Comissão antecessora e vota pela aprovação do PLS nesses termos. ${ }^{70}$

Ademais, frisa que embora o Estatuto da Criança e do Adolescente traga importantes inovações no que tange aos direitos dos filhos, ainda existe uma lacuna na legislação brasileira quanto à reparação do "descaso afetivo" e que esta seria devidamente preenchida pelo Projeto.

Já o segundo relatório é de 2011 e teve como responsável o exSenador Demóstenes Torres, que foi cassado em 2012.

\footnotetext{
69 OLIVEIRA, Patrícia. IN Portal de Notícias do Senado. Disponível em: http://www12.senado.gov.br/noticias/materias/2013/01/16/abandono-afetivo-de-filhos-pode-virarcrime.

70 CAMATA, Gerson. Parecer da Comissão de Constituição, Justiça e Cidadania sobre o Projeto de Lei $n^{\text {o }} 700$ de 2007 do Senado Federal, em tramitação. Disponível em: http://www.senado.gov.br/atividade/materia/detalhes.asp?p_cod_mate=83516
} 
Como já salientado, esse relatório praticamente repete o anterior, tanto no conteúdo, quanto no voto. Mais uma vez, o posicionamento é de integral concordância com as Emendas propostas pela Comissão de Constituição, Justiça e Cidadania, nos seus exatos termos, para que o Projeto seja aprovado. ${ }^{71}$

O último relatório elaborado na Comissão de Direitos Humanos e Legislação Participativa foi feito em 2012 e é assinado pelo Senador Eduardo Lopes.

Em seus argumentos para a aprovação do Projeto, o Senador, acrescentou além das razões já utilizadas pelos demais relatores, que:

"Por abundância, merece registro que o Estado Brasileiro é signatário de compromissos firmados por consenso internacional, que em nosso ordenamento legal ganham status de Emenda Constitucional (art. $5^{\circ}, \S 3^{\circ}$ ), que também apontam para a necessidade de aprimoramento das normas legais assecuratórias dos direitos das nossas criança e adolescentes, inclusive um adotado há mais de meio século (...)" ${ }^{72}$

Além disso, se valeu do voto da Ministra Nancy Andrighi, na decisão de maio de 2012, para demonstrar a gravidade do dano causado no abandono afetivo.

Outro ponto de grande relevância do relatório foi a manifestação de aquiescência do Senador com a Emenda da Comissão de Constituição, Justiça e Cidadania quanto à caracterização do abandono afetivo como ilícito penal. Interessante notar que o relator deixa claro que concorda com a Emenda apenas por temer que esse ponto inviabilize a aprovação do PLS e não por discordar dessa tipificação.

\footnotetext{
71 TORRES, Demóstenes. Parecer da Comissão de Constituição, Justiça e Cidadania sobre o Projeto de Lei $\mathrm{n}^{\circ} 700$ de 2007 do Senado Federal, em tramitação. Disponível em: http://www.senado.gov.br/atividade/materia/detalhes.asp?p_cod_mate=83516

72 LOPES, Eduardo. Parecer da Comissão de Constituição, Justiça e Cidadania sobre o Projeto de Lei $\mathrm{n}^{\mathrm{o}} 700$ de 2007 do Senado Federal, em tramitação. Disponível em: http://www.senado.gov.br/atividade/materia/detalhes.asp?p_cod_mate=83516
} 
Finalizou afirmando que não concorda com a Emenda de $n^{\circ}$ 01-CCJ, por entender que não se deve tornar obrigatória a visita dos pais aos filhos e nem a sua convivência.

Assim, votou pela aprovação do Projeto de Lei com as Emendas $n^{\circ} 2$ à 6 da Comissão de Constituição, Justiça e Cidadania do Senado.

Diante de todo o exposto, tudo nos leva a crer que o parecer terminativo da Comissão de Direitos Humanos e Legislação Participativa também será favorável à conversão do Projeto do Senador Crivella em lei. Agora só nos resta aguardar e esperar para ver se a tendências se confirmam e quando isso será feito.

\section{2- O Projeto de Lei no 4.294 de 2008 da Câmara dos Deputados}

Na Câmara dos Deputados, assim como ocorre no Senado Federal, também existe um Projeto de Lei que busca regulamentar a indenização por dano moral em razão de abandono afetivo.

Posterior ao PLS 700/2007, o Projeto de Lei 4.294 de 2008 tem significativas diferenças em relação ao primeiro. Para que fiquem claras as mudanças objetivadas é preciso que se exponha o conteúdo do Projeto em questão e sua tramitação. É dessa tarefa da qual nos encarregaremos agora.

O PL de autoria do Deputado Federal Carlos Bezerra visa à alteração de um artigo do Código Civil e outro do Estatuto do Idoso para estabelecer a reparação pecuniária por abandono afetivo. 
O primeiro dos três artigos da proposta prevê o acréscimo de parágrafos tanto no artigo 1.632 do Código Civil quanto no artigo $3^{\circ}$ do Estatuto do Idoso. ${ }^{73}$

No artigo $2^{\circ}$ a previsão é de que o artigo 1.632 da Lei 10.406 de janeiro de 2002 (CC/2002) seja acrescido de um parágrafo único com a seguinte redação: “O abandono afetivo sujeita os pais ao pagamento de indenização por dano moral.". ${ }^{74}$

Finalmente, o artigo $3^{\circ}$ do Projeto determina que o artigo $3^{\circ}$ da Lei 10.741 de $1^{\circ}$ de outubro de 2003 (Estatuto do Idoso) deve ser modificado de modo que o seu parágrafo único se transforme em parágrafo $1^{\circ}$ e seja acrescido um parágrafo $2^{\circ}$ determinando: “O abandono afetivo sujeita os filhos ao pagamento de indenização por dano moral". 75

Em sua justificação, o autor da proposição em questão afirma que as obrigações existentes entre pais e filhos não se resumem a prestação de auxílio material, devendo ser observadas as necessidades de afeto e atenção, indispensáveis tanto ao "desenvolvimento da personalidade dos filhos" quanto ao "respeito às pessoas de maior idade". ${ }^{76}$

Salientou ainda, que no caso dos filhos menores a rejeição proveniente do abando afetivo causam enormes prejuízos em sua personalidade. E no dos idosos, gerariam grande tristeza e solidão, de modo

\footnotetext{
73 Artigo $1^{\circ}$ do Projeto de Lei no 4.294 de 2008 da Câmara dos Deputados, em tramitação. Disponível em: http://www.camara.gov.br/proposicoesWeb/fichadetramitacao?idProposicao=415684

74 Artigo $2^{\circ}$ do Projeto de Lei n ${ }^{\circ} 4.294$ de 2008 da Câmara dos Deputados, em tramitação. Disponível em: http://www.camara.gov.br/proposicoesWeb/fichadetramitacao?idProposicao $=415684$

${ }^{75}$ Artigo $2^{\circ}$ do Projeto de Lei n ${ }^{\circ} 4.294$ de 2008 da Câmara dos Deputados, em tramitação. Disponível em: http://www.camara.gov.br/proposicoesWeb/fichadetramitacao?idProposicao=415684

76 BEZERRA, Carlos. Justificação do Projeto de Lei nº 4.294 de 2008 da Câmara dos Deputados, em tramitação. Disponível em: http://www.camara.gov.br/proposicoesWeb/fichadetramitacao?idProposicao=415684
} 
a causar "deficiências funcionais" e interferir no "interesse com sua própria vida". 77

Resta evidente, portanto, que o PL em tela vai além do PLS do Senado, pois visa estabelecer não apenas a indenização por abandono afetivo para os filhos rejeitados por seus pais, mas também, a mesma reparação para os pais idosos que não sejam devidamente cuidados por seus filhos.

Após a sua apresentação, o Projeto de Lei foi distribuído para duas Comissões da Casa Legislativa, a saber: Comissão de Seguridade Social e Família e a Comissão de Constituição e Justiça e de Cidadania.

A primeira a apreciar a proposta foi a Comissão de Seguridade Social e Família. No ano de 2010, sob a relatoria da Deputada Jô Moraes, a referida Comissão deu um parecer no qual votou de forma favorável à aprovação do Projeto.

$\mathrm{O}$ parecer em tela se fundou nos argumentos de que o abandono afetivo causa um inegável dano psicológico ao filho, decorrentes da absorção de sentimentos de rejeição e indiferença. ${ }^{78}$

Além disso, segundo o entendimento em voga, a noção de dano moral indenizável é dinâmica, de forma que o que antes era considerado um mero aborrecimento pode se tornar uma questão que mereça a atenção do Poder Público. 79

Desse modo, seria extremamente "útil e conveniente" que se criasse uma previsão legal estabelecendo a indenização por dano moral decorrente

\footnotetext{
${ }^{77}$ BEZERRA, Carlos. Justificação do Projeto de Lei no 4.294 de 2008 da Câmara dos Deputados, em tramitação. Disponível em: http://www.camara.gov.br/proposicoesWeb/fichadetramitacao?idProposicao=415684

${ }^{78}$ Parecer da Comissão de Seguridade Social e Família sobre o Projeto de Lei n ${ }^{\circ} 4.294$ de 2008 da Câmara dos Deputados, em tramitação. Disponível em: http://www.camara.gov.br/proposicoesWeb/fichadetramitacao?idProposicao=415684

${ }^{79}$ Parecer da Comissão de Seguridade Social e Família sobre o Projeto de Lei no 4.294 de 2008 da Câmara dos Deputados, em tramitação. Disponível em: http://www.camara.gov.br/proposicoesWeb/fichadetramitacao?idProposicao=415684
} 
de abandono afetivo, inclusive como uma maneira de reforçar os "laços familiares" e desestimular que outras pessoas cometam o mesmo abandono. $^{80}$

No que tange a análise por parte da Comissão de Constituição e Justiça e de Cidadania, cabe esclarecer que ainda não existe um parecer definitivo da mesma e sim, o parecer do relator designado para o Projeto, datado de 2012.

Interessante notar ainda, que em seu relatório, o Deputado Federal Antônio Bulhões, não só analisa a questão do abandono afetivo, como também propõe um substitutivo ao Projeto de Lei, que no seu entendimento, melhor se adequaria ao tema. Nada mais adequado então, do que averiguarmos quais as proposições feitas pelo nobre Deputado.

Logo de início, o relator citou e transcreveu as disposições presentes nos artigos 1.634, 1.637 e 1.638 do Código Civil, por serem esses os que versam sobre exercício, suspensão e extinção do poder familiar. ${ }^{81}$

Em sequência, frisou que o tema do abandono afetivo é controverso, mas firmou seu entendimento de que embora não se possa obrigar ninguém a amar ou a manter uma relação afetiva, não se pode ignorar que existem casos em que há um abandono de tal magnitude que sérios danos são causados e precisam de uma reparação. Acrescentou, inclusive, que isso vale tanto para os filhos afetivamente abandonados, quanto para os idosos. E nesse mesmo sentido, destacou os artigos do Estatuto do Idoso que entendeu pertinentes para o caso. ${ }^{82}$

\footnotetext{
${ }^{80}$ Parecer da Comissão de Seguridade Social e Família sobre o Projeto de Lei n ${ }^{\circ} 4.294$ de 2008 da Câmara dos Deputados, em tramitação. Disponível em: http://www.camara.gov.br/proposicoesWeb/fichadetramitacao?idProposicao=415684

81 BULHÕES, Antônio. IN Relatório da Comissão de Constituição e Justiça e de Cidadania sobre o Projeto de Lei n ${ }^{\circ} 4.294$ de 2008 da Câmara dos Deputados, em tramitação. Disponível em: http://www.camara.gov.br/proposicoesWeb/fichadetramitacao?idProposicao=415684

82 BULHÕES, Antônio. IN Relatório da Comissão de Constituição e Justiça e de Cidadania sobre o Projeto de Lei nº 4.294 de 2008 da Câmara dos Deputados, em tramitação. Disponível em: http://www.camara.gov.br/proposicoesWeb/fichadetramitacao?idProposicao=415684
} 
Para o ilustre Deputado Federal, cada caso concreto terá que ser devidamente avaliado pelo magistrado competente, que deverá averiguar a extensão do dano causado. Mas que seria "prudente" que a possibilidade de reparação fosse "explicitada" pela legislação. ${ }^{83}$

Finalmente, votou pela aprovação do Projeto de Lei, na forma do substitutivo que elaborou e que analisaremos agora.

No artigo $1^{\circ}$ de seu substitutivo propõe que sejam acrescidos dispositivos ao Código Civil e ao Estatuto do Idoso, dispondo sobre indenização por dano moral decorrente de abandono afetivo. ${ }^{84}$

$\mathrm{O}$ artigo $2^{\circ}$ da mesma proposição dispõe que o artigo 1.638 do Código Civil seja acrescido de um parágrafo único, que assim versaria: “Comprovado o abandono afetivo, caberá indenização por dano moral ao filho". 85

O terceiro artigo do substitutivo, por sua vez, estabelece que o artigo $5^{\circ}$ do Estatuto do Idoso também passe a vigorar acrescido de um parágrafo único, no seguinte sentido: “Comprovado o abandono afetivo por parte da família, caberá indenização por dano moral ao idoso". ${ }^{86}$

Já o último artigo da proposta do relator estabelece que a lei entraria em vigor na data de sua publicação. ${ }^{87}$

\footnotetext{
${ }^{83}$ BULHÕES, Antônio. IN Relatório da Comissão de Constituição e Justiça e de Cidadania sobre o Projeto de Lei ${ }^{\circ} 4.294$ de 2008 da Câmara dos Deputados, em tramitação. Disponível em: http://www.camara.gov.br/proposicoesWeb/fichadetramitacao?idProposicao=415684

${ }^{84}$ Artigo $1^{\circ}$ do substitutivo ao Projeto de Lei no 4.294 de 2008 da Câmara dos Deputados, em tramitação, proposto pelo Deputado Antônio Bulhões na Comissão de Constituição e Justiça e de Cidadania. Disponível em: http://www.camara.gov.br/proposicoesWeb/fichadetramitacao?idProposicao=415684

${ }^{85}$ Artigo $2^{\circ}$ do substitutivo ao Projeto de Lei $n^{\circ} 4.294$ de 2008 da Câmara dos Deputados, em tramitação, proposto pelo Deputado Antônio Bulhões na Comissão de Constituição e Justiça e de Cidadania. Disponível em: http://www.camara.gov.br/proposicoesWeb/fichadetramitacao?idProposicao=415684

${ }^{86}$ Artigo $3^{\circ}$ do substitutivo ao Projeto de Lei $n^{\circ} 4.294$ de 2008 da Câmara dos Deputados, em tramitação, proposto pelo Deputado Antônio Bulhões na Comissão de Constituição e Justiça e de Cidadania. Disponível em: http://www.camara.gov.br/proposicoesWeb/fichadetramitacao?idProposicao=415684 ${ }^{87}$ Artigo $4^{\circ}$ do substitutivo ao Projeto de Lei $n^{\circ} 4.294$ de 2008 da Câmara dos Deputados, em tramitação, proposto pelo Deputado Antônio Bulhões na Comissão de Constituição e Justiça e de
} 
Agora caberá a Comissão e aos demais Deputados da Casa decidir pela aprovação do texto original, do substitutivo proposto ou pela rejeição de ambos.

Mas, de todo modo, paira no horizonte mais uma possibilidade de uma legislação específica sobre a indenização por dano moral decorrente de abandono afetivo, sendo essa de maior abrangência e abarcando ainda essa proteção para os idosos. 


\section{Conclusão}

Conforme observamos ao longo desse trabalho, a noção de que o desamparo afetivo pode ensejar uma reparação ao filho abandonado é resultado de uma nova era do Direito de Família, iniciada com a Carta Magna de 1988, que espelha valores essenciais que norteiam a sociedade atual.

Com a volta, historicamente recente, da democracia ao Estado Brasileiro, é mais do que normal que se leve certo tempo até que os princípios basilares da nossa Constituição Federal possam ser consolidados, efetivados e irradiados para todos os ramos do Direito e para o âmago de nossa sociedade.

Embora desde 1988 já exista a previsão constitucional de priorização do princípio da dignidade da pessoa humana, era mais do que previsível que fosse necessária uma evolução progressiva e gradual da mentalidade social, para que se pudesse implementar todos os direitos e deveres que dele decorrem.

E é justamente diante desse cenário, que se deu o surgimento do Estatuto da Criança e do Adolescente e Código Civil de 2002. Foi com o advento da criação dessas duas leis, que se "colocou por terra", toda e qualquer dúvida que pudesse existir sobre o surgimento de uma nova realidade no ordenamento pátrio.

Nos dias atuais, não resta mais qualquer questionamento de que cada um dos indivíduos que compõem o núcleo familiar devem ser protegidos de acordo com suas individualidades e necessidades, de modo com que a família como um todo possa ser fortalecida. Diante disso, é indubitável a necessidade de que os Princípios da dignidade humana, do melhor interesse 
da criança, da paternidade responsável, dentre outros, pautem a conduta dos pais para com seus filhos.

Perante esse prisma, não há mais possibilidade de que os pais continuem se escusando de cumprir seus deveres de cuidado, convívio, educação, orientação, apoio emocional e material e porque não dizer, afeto, para com aqueles a quem deram a vida ou escolheram adotar.

Não existe mais espaço para que impere uma lógica meramente patrimonialista ou, quiçá, machista, na qual apenas a mãe tem obrigações educacionais.

Resta mais do que comprovado pela ciência moderna, que a participação ativa e presente de ambos os genitores é fundamental para o desenvolvimento completo e sadio de crianças e adolescentes. E, por isso, nosso ordenamento jurídico, acertadamente, determinou, por meio de sua força coercitiva, a exigência do cumprimento de deveres que já eram cristalinos no campo ético e moral.

Contudo, mesmo com as nítidas imposições trazidas pelos mais diversos diplomas legais, sejam eles a Constituição Federal ou as Convenções Internacionais, inúmeros genitores preferiram ignorar a importância de cuidar e afeiçoar os seus filhos. E durante um bom tempo, isso ocorreu com a conivência e inércia dos Poderes Judiciário e Legislativo.

Todavia, conforme demonstramos, isso vem se alterando com o passar do tempo. Doutrinadores, operadores do Direito e legisladores despertaram para a gravidade de se permitir que esse desamparo prosseguisse. Um indivíduo emocionalmente abandonado por aqueles que mais deveriam lhe amar, é um ser humano propício a desenvolver uma série de patologias e barreiras inerentes à dor. E o padecimento interior de cada um dos componentes da instituição familiar, representa o enfraquecimento da família e, consequentemente, da sociedade como um todo. 
Não é possível que o Poder Judiciário obrigue um pai ou uma mãe a amar seu filho como esse deveria. Mas é obrigação dos nossos nobres julgadores, fazer valer todos os deveres impostos por lei. Se esses deveres são descumpridos e existe uma violação dos direitos dos filhos que configura a caracterização da existência dos elementos ensejadores da responsabilidade civil, como ocorre no abando afetivo, não podem os juízes e Tribunais deixarem de cumprir a sua função.

As atuais previsões legais existentes em nosso ordenamento jurídico já deixam nítida a possibilidade de se indenizar o abandono afetivo. Mas como, apesar de todo o avanço doutrinário e jurisprudencial, ainda existe grande resistência a essa reparação, seria extremamente importante que os Projetos de Lei acerca do tema viessem a se concretizar na forma de normas jurídicas. Pois assim, não existiria mais espaço para que se negasse uma compensação, mais do que justa, para quem já tanto sofreu.

Afinal de contas, ou se fortalece e protege a base de toda uma estrutura, ou se corre o sério risco de que "tudo desabe sobre nossas cabeças". 


\section{Bibliografia}

ANDREKOWISK, Lauane Gomes Braz. Dano moral nas ações de filiação.

Revista de Direito Privado, n. 25, jan./mar. 2006.

BRASIL, Constituição (1998). Constituição da República Federativa do Brasil. Distrito Federal: Senado, 1988.

BRASIL. Lei $\mathrm{n}^{\circ} 8.069$, de 13 de julho de 1990, institui o Estatuto da Criança e do Adolescente.

BRASIL. Lei n ${ }^{\circ} 10.406$, de 10 de janeiro de 2002, institui o Código Civil. CÂMARA DOS DEPUTADOS. Projeto de Lei no 4.294 de 2008, em tramitação. Disponível em: http://www.camara.gov.br/proposicoesWeb/fichadetramitacao?idProposica $\underline{0=415684}$

CAMPOS, Marília. COLTO, Antonio Carlos Mathias. "Cuidando do Cuidado". IN PEREIRA, Tânia da Silva. OLIVEIRA, Guilherme de. “Cuidado \& Vulnerabilidade”. Editora Atlas S.A. São Paulo. 2009.

CASTRO, Leonardo. O preço do abandono afetivo. IN Revista IOB de Direito de Família, n. 46, fev./mar. 2008.

COSTA, Maria Isabel Pereira da. "A Responsabilidade Civil dos Pais Pela Omissão do Afeto na Formação da Personalidade dos Filhos" IN MADALENO, Rolf. MILHORANZA, Mariângela Guerreiro. “Atualidades do Direito de Família e Sucessões”. Editora Notadez. 2008.

DIAS, Maria Berenice. "Manual de Direito das Famílias". Editora Revista dos Tribunais, 6 $6^{\text {a }}$ edição, São Paulo, 2010.

GAMA, Guilherme Calmon Nogueira da e ORLEANS, Helen Cristina Leite de Lima. "Responsabilidade Civil nas Relações Familiares". IN Revista Brasileira de Direito das Famílias e Sucessões, No 24, Out-Nov 2011. 
HIRONAKA, Giselda Maria Fernandes Novaes. Aspectos jurídicos da relação paterno-filial. Carta Forense, São Paulo, ano III, n. 22, p. 3, mar. 2005 .

MADALENO, Rolf. "O custo do abandono afetivo". Disponível em: http://www.rolfmadaleno.com.br/rs/index.php?option=com_content\&task= view\&id=943\&Itemid=39. Acessado em 15/11/2012.

MARTINS, Rosa. "Responsabilidades Parentais no século XXI: a tensão entre o direito de participação da criança e a função educativa dos pais" IN PEREIRA, Tânia da Silva. OLIVEIRA, Guilherme de. "Cuidado \& Vulnerabilidade”. Editora Atlas S.A. São Paulo. 2009.

MORAES, Maria Celina Bodin de. "Deveres Parentais e Responsabilidade Civil” IN Revista Brasileira de Direito das Famílias e Sucessões. Ano VII, No 31. Ago-Set 2005

NOVAES, Simone Ramalho. Abandono moral. IN Revista da EMERJ, v. 10, n. 40, 2007.

PEREIRA, Rodrigo da Cunha. "Responsabilidade Civil por Abandono Afetivo". IN Revista Brasileira de Direito das Famílias e Sucessões. Nº 29. Ago-Set 2012. Disponível em: http://www.magisteronline.com.br.

PEREIRA. Tânia da Silva. O "Cuidado" chega ao STJ. IN Revista Brasileira de Direito de Família e Sucessões, N 19, DEZ-JAN 2011.

RIOGRANDE DO SUL, 2 ${ }^{\mathrm{a}}$ Vara Cível da Comarca de Capão da Canoa, Processo Cível no 1411030012032-0, Juiz Mário Romano Maggioni, Capão da Canoa, 15 set. 2003.

ROSSOT. Rafael Bucco. “O Afeto nas Relações Familiares e a Faceta Substancial do Princípio da Convivência Familiar”. IN Revista Brasileira de Direito de Família e Sucessões, Nº 9, Abril-Maio 2009.

SANTOS. Luiz Felipe Brasil. "Pais, Filhos e Danos". Disponível em: http://direitodefamiliars.blogspot.com.br/2011/06/doutrina-pais-filhos-edanos.html 
SÃO PAULO. $31^{\mathrm{a}}$ Vara Cível Central da Comarca de São Paulo, Processo Cível no 583.00.2001.036747-0, Juiz Luís Fernando Cirillo, São Paulo, 05 jun. 2004.

SCHEREIBER, Anderson. "Novas tendências da responsabilidade civil brasileira". IN: "Revista Trimestral de Direito Civil, v.22, abr./jun.2005.

SENADO FEDERAL. Projeto de Lei n ${ }^{\circ} 700$ de 2007, em tramitação. Disponível em: http://www.senado.gov.br/atividade/materia/detalhes.asp?p_cod_mate=835 $\underline{16}$

SILVA, Claudia Maria da. "Descumprimento do Dever de Convivência Familiar e Indenização por Danos á Personalidade do Filho". IN Revista Brasileira de Direito de Família, Ano VI, no 25- Ago-Set 2004.

SKAF, Samira. "Possibilidade Legal de Concessão de Dano Moral aos Filhos Abandonados Afetivamente pelos Pais, Frente ao Cometimento de Ato Ilícito". IN Revista Brasileira de Direito das Famílias e Sucessões. N ${ }^{o}$ 13. Dez-Jan 2010. Disponível em: http://www.magisteronline.com.br

SOUZA. Ivone M. Candido Coelho de. "Dano Moral por Abandono: Monetarizando o Afeto”. IN Revista Brasileira de Direito de Família e Sucessões, $N^{\circ}$ 13, Dez-Jan 2010.

STJ, Recurso Especial No 1.159.242-SP, Min. Rel. Nancy Andrighi, Brasília, 24 abr. 2012

STJ, Recurso Especial n ${ }^{\circ}$ 757.411-MG, Rel. Min. Fernando Golçalves, Brasília, 29 nov. 2005.

TARTUCE. Flávio. "Danos Morais por Abandono Moral”. IN Revista Brasileira de Direito das Famílias e Sucessões. Nº 7. Dez-Jan 2009.

TEIXEIRA, Ana Carolina Brochado. "Responsabilidade Civil e Ofensa à Dignidade Humana". IN Revista Brasileira de Direito de Família. Ano VII. N³2. Out-Nov 2005. 
TJ-MG, Apelação Cível No 1.0472.08.017785-1/001, Des. Rel. José Flávio de Almeida, Belo Horizonte, 09 nov. 2011.

TJMG, Apelação Cível $\mathrm{n}^{\circ}$ 208.550-5, Rel. Des. Unias Silva, Belo Horizonte, 01 abr. 2004.

TJ-RJ, Apelação Cível 0068032-79.2005.8.19.0001 (2007.001.45918), Des. Rel. Werson Rego, Rio de Janeiro, 22 nov. 2007.

TJ-RJ, Apelação Cível No 0005674-11.2006.8.19.0206, Des. Rel. Jose Carlos Paes, Rio de Janeiro, 21 mar. 2012.

TJRS, Apelação Cível no 70011681467, Rel. Des. Luiz Felipe Brasil Santos, Porto Alegre, 10 ago. 2005

TJRS, Apelação Cível no 70021427695, Rel. Des. Claudir Fidélis Faccenda, Porto Alegre, 29 nov. 2007.

TJ-RS, Apelação Cível No 70021592407, Sétima Câmara Cível, Des. Rel. Ricardo Raupp Ruschel, 14 mai 2008.

TJRS, Apelação Cível no 70044172401, Oitava Câmara Cível, Rel. Des. Luiz Felipe Brasil Santos, Porto Alegre, 13 de out. 2011.

TJRS, Embargos Infringentes n n $^{\mathbf{7}}$ 70000271379, Rel. Juiz Antônio Carlos Stangler Pereira, Porto Alegre, 11 ago. 2000.

TJ-SC, Apelação Cível No 2006.015053-0, Des. Rel. Monteiro Rocha, 08 mar. 2007.

TJ-SP, Apelação Cível No 361.389-4/2-00, Des. Rel. Daise Fajardo Nogueira Jacot, São Paulo, 26 nov. 2008.

TJ-SP, Apelação Cível No 5995064900, Des. Rel. Maia da Cunha, São Paulo, 11 dez. 2008.

TJ-SP, Apelação Cível No 9170835-24.2007.8.26.0000 (511.903-4/7-00), Des. Rel. Caetano Lagrasta, Rio de Janeiro, 12 mar. 2008. 